\title{
Monitoring of the Water Levels in the Wetlands of Fourmile Branch near the F and H Areas of SRS: September 1997 to December 1998
}

by

N. V. Halverson

RECEIVED

N. Halverson

Westinghouse Savannah River Company

Savannah River Site

Aiken, South Carolina 29808

K. L. Dixon

This paper was prepared in connection with work done under the above contract number with the U.S. Department of Energy. By acceptance of this paper, the publisher and/or recipient acknowledges the U.S. Government's right to retain a nonexclusive, royalty-free license in and to any copyright covering this paper, along with the right to reproduce and to authorize others to reproduce all or part of the copyrighted paper. 


\section{DISCLAIMER}

This report was prepared as an account of work sponsored by an agency of the United States Government. Neither the United States Government nor any agency thereof, nor any of their employees, makes any warranty, express or implied, or assumes any legal liability or responsibility for the accuracy, completeness, or usefulness of any information, apparatus, product or process disclosed, or represents that its use would not infringe privately owned rights. Reference herein to any specific commercial product, process or service by trade name, trademark, manufacturer, or otherwise does not necessarily constitute or imply its endorsement, recommendation, or favoring by the United States Government or any agency thereof. The views and opinions of authors expressed herein do not necessarily state or reflect those of the United States Government or any agency thereof.

This report has been reproduced directly from the best available copy.

Available for sale to the public, in paper, from: U.S. Department of Commerce, National Technical Information Service, 5285 Port Royal Road, Springfield, VA 22161, phone: (800) 553-6847,

fax: (703) 605-6900

email: orders@ntis.fedworld.gov

online ordering: http://www.ntis.gov/ordering.htm

Available electronically at http://www.doe.gov/bridge Available for a processing fee to U.S. Department of Energy and its contractors, in paper, from: U.S. Department of Energy, Office of Scientific and Technical Information, P.0. Box 62, Oak Ridge, TN 37831-0062, phone: (865)576-8401, fax: (865)576-5728 email: reportseadonis.osti.gov 


\section{DISCLAIMER}

Portions of this document may be illegible in electronic image products. Images are produced from the best available original document. 
mis

RECORDS ADMINISTRATION

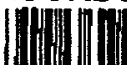

\section{Monitoring of the Water Levels in the Wetlands of Fourmile Branch} near the F and H Areas of SRS: September 1997 to December 1998 (U)

N. V. Halverson and K. L. Dixon

Savannah River Technology Center

Westinghouse Savannah River Company

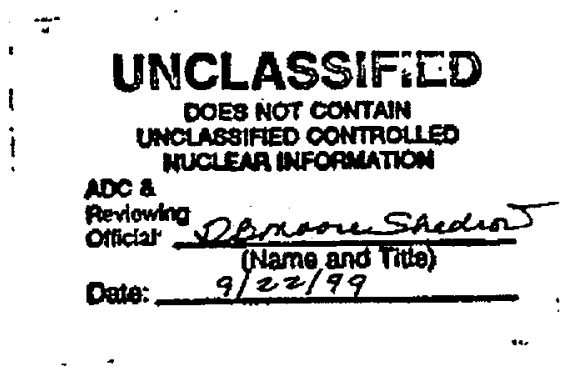

Savannah River Site

Aiken, SC 29802 


\title{
Monitoring of the Water.Levels in the Wetlands of Fourmile Branch near the F and H Areas of SRS: September 1997 to December 1998
}

\author{
N. V. Halverson and K. L. Dixon \\ Savannah River Technology Center \\ Westinghouse Savannah River Company \\ Aiken, SC 29802
}

\section{Executive Summary}

A network of twenty-three piezometers was used to measure hydraulic head in the water-table aquifer along the groundwater outcrop (i.e. seepline) at the F- and H-Area seeplines. The piezometers were installed to assess potential impacts of the F- and H-Area Groundwater Remediation Waste Treatment Units (WTUs) on the riparian wetland system located between the former F- and H-Area seepage basins and Fourmile Branch. Operation of the WTUs has the potential to lower the water table near the WTUs' extraction wells, potentially drying a portion of the nearby wetland areas. The piezometers were positioned specifically to target areas closest to the extraction wells. The purpose of the piezometer network is two-fold: 1) to establish baseline hydraulic head data for the water-table aquifer at the F- and H-Area seeplines prior to startup of the groundwater extraction/injection remediation system, and 2) to observe the effects of the remediation system on the water table levels after system start-up.

During the period September 1997 through December 1998, water levels were measured by hand monthly at each piezometer. For the fourteen piezometers equipped with data loggers, water levels were recorded every hour or half hour in addition to the monthly hand measurements. Results from 1998 were compared to results recorded before the WTUs began operating (the pre-operational period). In addition, all results recorded since the WTUs began operating (the operational period) were compared to the preoperational period. For F Area, January 1996 through March 1997 was used as the pre-operational period. For H Area, January 1996 through June 1997 was used as the pre-operational period. These preoperational periods span less than two years. Thus, whereas the pre-operational period data is useful for comparing with current water levels, it is not representative of the long-term average water levels at these locations.

The changes in the piezometer water elevations in 1998 were generally small and are expected to have had insignificant effects on the wetland system between the former F- and H-Area seepage basins and Fourmile Branch. During the operational period, most piezometers measured greater fluctuations in groundwater elevations than in the pre-operational period. Overall, the average change in the 1998 water elevations, compared to the pre-operational period elevations, was a $0.28 \mathrm{ft}$ increase for F-Area piezometers and a 0.32 foot decrease for $\mathrm{H}$-Area piezometers. When water elevation measurements were averaged for the entire operational period, the average change was a $0.10 \mathrm{ft}$ increase for F-Area piezometers and a $0.22 \mathrm{ft}$ decrease for $\mathrm{H}$-Area piezometers, compared to the pre-operational period elevations. 
Looking at individual "A" series piezometers, some exhibited increases in the average water elevation and some exhibited decreases. For nine of the piezometers, average groundwater levels in 1998 and for the entire operational period actually increased compared to levels measured in the pre-operational period. The piezometers showing increased average water elevations were FPZ001A, FPZ002A, FPZ004A, FPZ006A, FPZ007A, FPZ008A, HPZ002A, HPZ003A and HPZ006A. These increases may be a result of increased rainfall in the operational period (an average of 4.8 inches per month for $F$ Area and 5.0 inches per month for $\mathrm{H}$ Area) compared to the pre-operational period (an average of 3.9 inches per month for both areas). Only five of the piezometers recorded 1998 and operational period average water levels that were lower than pre-operational levels. These piezometers were FPZ003A, FPZ005A, HPZ001A, HPZOO2A and HPZ004A.

In twelve of the fourteen " $\mathrm{A}$ " series piezometer locations, average 1998 water levels changed by less than one foot from the pre-operational levels. The two piezometers with a greater than one foot change were FPZO02A (1.04 ft increase) and HPZ004A ( $3.12 \mathrm{ft}$ decrease). When water elevation measurements were averaged for the whole operational period, only HPZ004A exhibited a change of greater than six inches compared to the average pre-operational period elevation. The average water elevation at HPZ004A appears lower in 1998 than in previous years due to the wide elevation swings recorded during the period January through June 1998. The magnitude of the elevation swings and the fact that hand measurements during that period do not correlate with the data logger measurements are indicative of instrument error rather than actual changes in the piezometric head. Water elevation measurements at HPZO04A stabilized and returned to the pre-operational period level after June 1998.

Groundwater elevations have been measured monthly at three reference locations, FHR001, FHR002 and FHR003, since July 1997. Groundwater elevations at these locations during the pre-operational period are not available. The standard deviation of groundwater elevation measurements calculated at FHR002 was the highest of all the piezometer locations except HPZO04A (when calculated from the data logger measurements). At all three reference locations, groundwater elevations peaked between January and June 1998. Similar groundwater elevation peaks in the first half of 1998 were evident in most of the other piezometers. As would be expected, rainfall during this period was greater than during the latter half of 1998. The fact that most F- and H-Area piezometers recorded piezometric changes similar to those in the reference locations might indicate that the rise in groundwater levels during this period could be simply the result of natural causes.

The only information available on the pumping schedule for the WTU extraction wells at the time of this report was the total monthly volume pumped from each extraction well. From these data, it can be inferred that the WTUs were not operating steadily or at full capacity in 1998. However, the relationship between the WTU operations and the wetland ecosystem cannot be determined at this time. To determine the relative influence of rainfall and the WTUs on groundwater elevations along the seeplines, more detailed information on WTU operations, including system start-up and shut-down times and dates, and extraction rates and volumes, would be required. 


\section{TABLE OF CONTENTS}

Executive Summary i

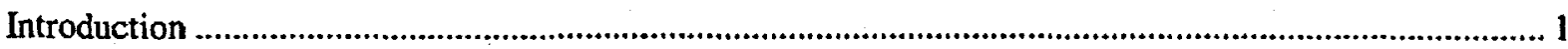

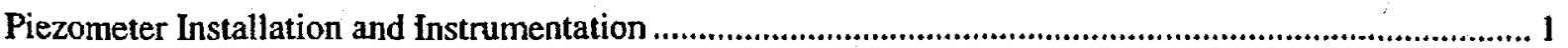

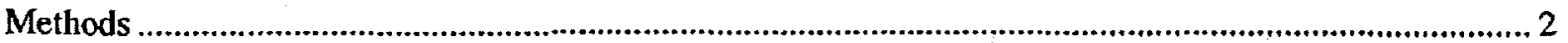

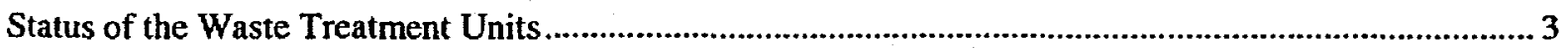

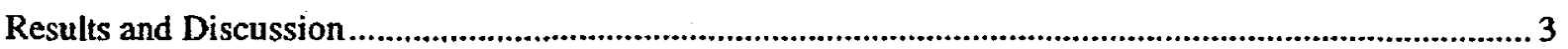

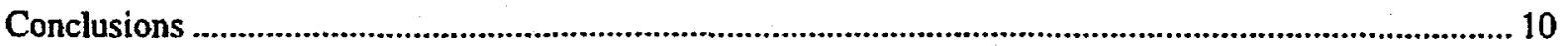

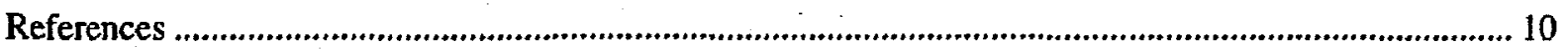

\section{LIST OF TABLES}

Table 1. Construction Information for the F- and H-Area Wetlands Piezometer Network...................... 12

Table 2. Piezometers with data logging equipment installed .................................................................. 13

Table 3. Groundwater Extraction (Thousands of Gallons) by the F-Area Groundwater Remediation

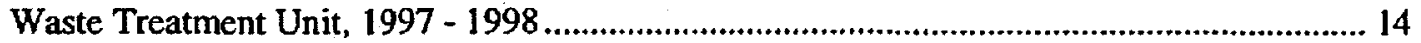

Table 4. Groundwater Extraction (Thousands of Gallons) by the H-Area Groundwater Remediation

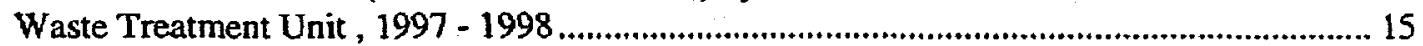

Table 5. Water Levels Measured by Electric Water-Level Tape at Individual Piezometers, September

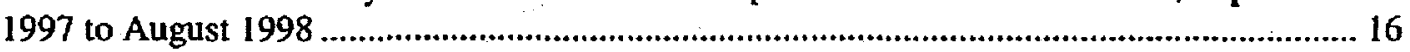

Table 6. Average, Maximum and Minimum Water Levels Measurements from September 1997 to

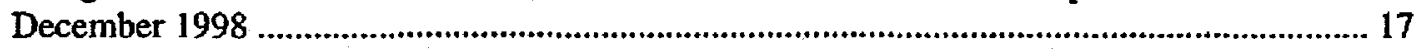

Table 7. Comparison of the 1998 Piezometer Water-Level Statistics with the Pre-Operation Period...., 18 Table 8. Comparison of the Piezometer Water-Level Statistics Before and After Waste Treatment Units Began Operating.

\section{LIST OF FIGURES}

Figure 1. Extraction/injection well locations and piezometer locations for the water table aquifer in FArea

Figure 2. Extraction/injection well locations and piezometer locations for the water table aquifer in $\mathrm{H}$ -

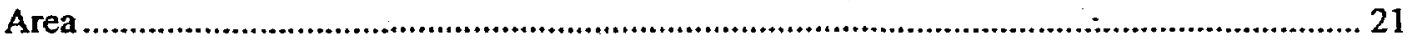

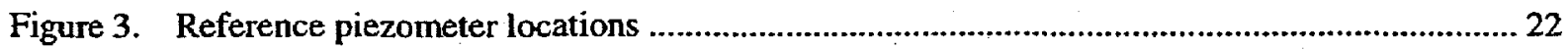

Figure 4. Water level elevations at location FPZ001A, January 1996 to December 1998 ................... 23

Figure 5. Water level elevations at location FPZ002A, January 1996 to December 1998 .................... 23

Figure 6. Water level elevations at location FPZ003A, January 1996 to December 1998 .................... 24

Figure 7. Water level elevations at location FPZ004A, January 1996 to December 1998 .................... 24

Figure 8. Water level elevations at locations FPZ005A and FPZ005B, January 1996 to December 199825

Figure 9. Water level elevations at locations FPZ006A and FPZ006B, January 1996 to December 199825 
Figure 10. Water level elevations at locations FPZ007A and FPZ007B, January 1996 to December 199826 Figure 11. Water level elevations at locations FPZ008A and FPZ008B, January 1996 to December 199826 Figure 12. Water level elevations at location HPZ00IA, January 1996 to December 1998 ..................... 27

Figure 13. Water level elevations at location HPZ002A, January 1996 to December 1998................... 28 Figure 14. Water level elevations at locations HPZ003A and HPZ003B, January 1996 to December 199828

Figure 15. Water level elevations at location HPZO04A, January 1996 to December 1998. 29

Figure 16. Water level elevations at locations HPZO05A and HPZ005B, January 1996 to December 19983029

Figure 17. Water level elevations at location HPZ006A, January 1996 to December 1998 3029

Figure 18. Water level elevations at location FHR001, January 1996 to December 1998 30

Figure 19. Water level elevations at location FHR002, January 1996 to December 1998

Figure 20. Water level elevations at location FHRC03, January 1996 to December 1998 31

Figure 21. Water Elevation at Piezometer FPZ001A and F-Area Rainfall $3 \%$

Figure 22. Water Elevation at Piezometer FPZ002A and F-Area Rainfall 33

Figure 23. Water Elevation at Piezometer FPZ003A and F-Area Rainfall 3 하

Figure 24. Water Elevation at Piezometer FPZ004A and F-Area Rainfall 35

Figure 25. Water Elevation at Piezometer FPZ005A and F-Area Rainfall 36

Figure 26. Water Elevation at Piezometer FPZ006A and F-Area Rainfall 38

Figure 27. Water Elevation at Piezometer FPZ007A and F-Area Rainfall 38

Figure 28. Water Elevation at Piezometer FPZ008A and F-Area Rainfall 38

Figure 29. Water Elevation at Piezometer HPZ001A and H-Area Rainfall. 4639

Figure 30. Water Elevation at Piezometer HPZOO2A and H-Area Rainfall

Figure 31. Water Elevation at Piezometer HPZ003A and H-Area Rainfall $4 \boldsymbol{t}$

Figure 32. Water Elevation at Piezometer HPZ004A and H-Area Rainfall 42

Figure 33. Water Elevation at Piezometer HPZ005A and H-Area Rainfall

Figure 34. Water Elevation at Piezometer HPZ006A and H-Area Rainfall

Figure 35. Typical Groundwater Response to Rainfall .

Figure 36. Typical Diumal Pattern in Groundwater Elevation 


\section{Introduction}

Seepage basins in the $F$ and $H$ Areas of the Savannah River Site (SRS) received low-level radioactive wastewater from the nuclear materials separations facilities. This wastewater consisted mostly of sodium hydroxide, nitric acid, low levels of various radionuclides (primarily tritium), and some metals (Killian et al., 1985a, b). Discharges to the seepage basins were discontinued in 1988 and the basins were capped and sealed in 1990.

As a result of basin operations, groundwater beneath and down-gradient of the basins was contaminated. The contamination is located primarily in the water-table aquifer and in the Barnwell/McBean Aquifer. Near the seepage basins in both $F$ and $H$ Area, groundwater flows toward Fourmile Branch. The water-table aquifer discharges to the wetlands and Fourmile Branch whereas the Barnwell/McBean Aquifer discharges primarily to Fourmile Branch. Contaminants originating from the seepage basins have been detected in shallow groundwater outcrops (i.e. the seepline) in the wetlands along Fourmile Branch in both $F$ and H Areas (Haselow et al., 1990; Dixon et al., 1993; Dixon and Rogers, 1993, Dixon et al., 1994).

Groundwater Remediation Waste Treatment Units (WTU) have been installed in $F$ and $H$ Areas in accordance with a Resource Conservation and Recovery Act (RCRA) Hazardous Waste Part B Permit. The WTUs include a network of extraction and injection wells to maintain hydraulic control of the $10,000 \mathrm{pCi} / \mathrm{ml}$ tritium plume. Figures 1 and 2 show the locations of the extraction/injection wells for the water-table aquifer (Aquifer Zone $\mathrm{IIB}_{2}$ ) in $\mathrm{F}$ Area and $\mathrm{H}$ Area, respectively. The extraction well numbers have the prefix "FEX" or "HEX" and the injection well numbers have the prefix "FIN" or "HIN."

Models simulating the operation of the WTUs predicted decreases in the water level of up to five feet at the seepline and in the wetlands nearby (Dixon 1995). Decreases in water levels associated with drawdown near the extraction wells could result in drying of a portion of the wetlands, and an overall movement of the seepline towards Fourmile Branch. Chronic depression of the water table at the wetlands, and the associated reversal in direction of groundwater flow, could alter the wetland plant and animal communities in this area. Further, changes in the hydrology of the wetlands would impact contaminant transport and contaminant concentrations at the new seeplines.

Changes in water levels in and near the wetlands must be monitored to assess the impacts of the remediation system on the wetlands. To establish a baseline, hydraulic head data for the water-table aquifer at both the F- and H-Area seeplines needed to be collected for a period before the groundwater extraction system began operating. Hydraulic head data collected after the extraction system began operating could be compared to the baseline data to determine whether any wetland impacts that may be observed following startup of the extraction/injection system are due to system operation or natural causes.

To accomplish this, a network of piezometers was established in 1996 in the wetlands of Fourmile Branch in both $\mathrm{F}$ and $\mathrm{H}$ Areas (Dixon, 1996). Currently, this network consists of twenty-three piezometers at seventeen different locations. The purpose of this report is to present the results of the monthly and continuous water level measurements.

\section{Plezometer Installation Instrumentation}

A total of twenty-three water-table piezometers has been installed at seventeen locations in the wetlands of Fourmile Branch near $F$ and $H$ Areas since January 1996. During January and May of 1996, twenty of the piezometers were installed at fourteen locations in a network in both F (Figure 1) and H Areas (Figure 2). These piezometers have the prefixes FPZ and HPZ, respectively. The network was designed to outline the current seepline, focusing on those areas expected to be most impacted by the remediation system. At locations with 
installed in clusters so that the piezometric surface could be measured for each layer. The deeper piezometers have well numbers with the suffix " $A$ ", and the shallow piezometers have the suffix "B".

During June 1997, three additional piezometers were installed in a reference area located in the wetlands of Fourmile Branch, but outside the area of influence of the remediation system. These piezometers have the prefixes FHR (Figure 3). Water level changes observed in these reference piezometers could be compared to changes observed in the FPZ and HPZ piezometers to help distinguish between natural variation and treatment system impacts.

With the exception of FPZ003A, all piezometers were installed using hand augering equipment ( 3

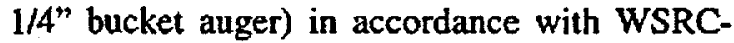
3Q5 (Chapter 7) procedures. Installation methods are detailed in Dixon (1996). Piezometer FPZ003A, which is located in an upland area, was installed using a hollow stem augering method due to the depth to the water table at this location. Table 1 gives the piezometer construction information for all the piezometers (FPZ, HPZ, and FHR series).

To investigate the natural water level variability in the Fourmile Branch riparian wetland system, nine piezometers were equipped with data logging equipment in 1996 to allow continuous water level monitoring. Five additional piezometers were equipped with data loggers in 1998. Because the frequency, magnitude, and duration of these natural variations are unknown, more frequent monitoring is required to determine these characteristics. Variation in the hydrologic system in and around the wetlands is expected to increase following startup of the extraction/injection system. Variations are expected to be more pronounced at those locations closest to the extraction wells. Thus, the piezometers closest to the extraction wells were chosen for initial instrumentation.

The piezometers selected for instrumentation are listed in Table 2 and shown in Figures 1 and 2. Table 2 also lists the date the data logger was installed for each piezometer. Each of the nine piezometers originally selected for instrumentation was equipped with a pressure transducer (5 psig range) controlled by a Campbell Scientific, Inc. CR10X data logger. In-Situ Inc. Troll Model SP4000 data loggers were installed in the five additional piezometers selected in 1998.

Several of the Campbell data loggers malfunctioned for various periods of time. Known causes for the malfunctions included a lightning strike, animal damage to the exterior transducer cabling, battery problems stemming from animal damage to the solar panel cable, a tree falling on the equipment and other interferences. The equipment was repaired and restored to functioning each time a malfunction occurred. Additional measures, such as enclosing exterior cabling in conduit, were taken to prevent further interruptions in data collection. Other situations could cause the sensors to temporarily exceed their range, resulting in sudden very low elevation readings. Data recorded during periods when the data loggers were not functioning properly were deleted.

In early 1999, the Campbell data loggers were all replaced with Troll data loggers. The new data loggers are completely enclosed in the piezometer casing, thus increasing the probability of uninterrupted data collection.

\section{Methods}

Water levels in the piezometers were measured monthly using an electric water-level tape. From these measurements, the elevation of the water table was determined for each location. Additionally, the water level of Fourmile Branch was measured at two locations. These two stream sites were located where Road C4 and Road El cross Fourmile Branch.

For the piezometers equipped with data loggers, water level measurements were monitored continuously at each location and averaged every thirty minutes for the CR10X data loggers and every hour for the Troll data loggers. 


\section{Status of the Waste Treatment Units}

The F-Area Groundwater Remediation WTU was in a start-up mode during the first and second quarters of 1997, operating a total of 100 hours. The facility operated in a shake-down mode during the third and fourth quarters of 1997, extracting, treating and reinjecting approximately 1.6 million gallons of water. The WTU operated only 6.8 percent of the time during that period. Flow rates were limited due to system testing, and full-operation was not initiated (WSRC 1998a). The WTU continued in the shake-down mode during first and second quarters 1998, extracting, treating and reinjecting approximately 1.5 million gallons of water. The WTU operated only 8.4 percent of the time during that period (WSRC 1998b). The F-Area Groundwater Remediation WTU did not operate during these quarters.

The shakedown mode continued for the F-Area Groundwater Remediation WTU throughout the third and fourth quarters of 1998. Approximately 12.8 million gallons of groundwater were extracted, treated and reinjected. Pumping rates still were not consistent due to significant system downtime (WSRC 1999a). The monthly volumes of groundwater treated are shown in Table 3.

The H-Area WTU also operated in a shakedown mode during the third and fourth quarters of 1997, extracting and treating and reinjecting approximately 1.2 million gallons of groundwater. Flow rates were limited due to system testing and limited injection well capacity. The WTU operated only 5.2 percent of the time during these quarters (WSRC 1998c). The WTU continued in the shake-down mode during first and second quarters 1998, extracting and treating approximately 4.2 million gallons and reinjecting about 4.1 million gallons of groundwater. The WTU operated only 16.6 percent of the time during that period (WSRC 1998d). The shakedown mode continued throughout the third and fourth quarters of 1998 as well. Approximately 10.7 million gallons of groundwater were extracted, treated and reinjected. However, pumping rates still were not consistent due to significant system downtime (WSRC 1999b). The monthly volumes of groundwater treated are shown in Table 4.

\section{Results and Discussion}

Rainfall totals for 1996, 1997 and 1998 were 46.4, 58.9 and 55.0 inches for F Area and 44.3, 57.7 and $\mathbf{5 7 . 8}$ for $H$ Area, respectively (Hunter 1999). Monthly rainfall calculated for the preoperational period was 3.9 inches per month for both $\mathrm{F}$ and $\mathrm{H}$ Areas. Monthly rainfall calculated for the operational period was 4.8 inches per month for F Area and 5.0 inches per month for H Area.

Results from the monthly water level measurements for the period of September 1996 through December 1998 are presented in Table 5. Summary statistics for each location are presented in Table 6. Table 6 also presents summary statistics based on the data logger measurements for the period from September 1997 to December 1998.

These two sets of statistics were not expected to be the same because they were based on data measured two different ways. The elevation measured monthly by electric tape represents a single point in time, which may or may not be representative of the whole range of water levels for the entire month. For locations where the water elevation swings over a large range, a single monthly measurement might be taken at an extreme point of the swing, thus giving the false impression that the water level is much higher or lower than the previous month. In contrast, water elevations measured at a location where the water level does not experience much change are likely to be representative of the whole range of elevations at that location. In contrast, an individual data point from the data loggers was the calculated average water level recorded for a half-hour period. Therefore, even the measurements by the data loggers may not represent the true maximum and minimum water elevations, though they would provide a good estimate of the true average water elevation. 
The greatest difference in results between the two types of measurements (i.e. manual vs. data logger) was in piezometer HPZ004A, in which the average elevation calculated from the continuous measurements was 2.6 feet lower than the elevation calculated from the monthly measurements. For the other piezometers, the average elevations calculated by the two methods differed by less than 4 inches, except for those piezometers instrumented in August 1998: FPZ003A, FPZ007A, FPZ008A, HPZ001A and HPZ006A. The piezometers instrumented in August 1998 have not recorded a full year of data, so the calculated average water elevations would not be expected to be representative of the entire year.

Table 7 compares the 1998 groundwater elevations with the elevations recorded before the WTUs began operating. All available piezometer data that preceded the startup of the WTUs was used for this comparison. For F Area, January 1996 through March 1997 was used as the pre-operational period. For $\mathrm{H}$ Area, January 1996 through June 1997 was used as the pre-operational period (WSRC 1997a, WSRC 1998b). These pre-operational periods span less than two years. Thus, while the pre-operational period data may be useful for comparison with current water levels, it cannot truly represent the long-term average water levels at these locations.

In general, maximum, minimum and average water levels were higher in 1998 for the F-Area " $A$ " series piezometers than in the preoperational period. The largest change in average elevation occurred in FPZ002A, with a rise of slightly more than one foot compared to pre-operational levels. The average change in the water elevation was a $0.28 \mathrm{ft}$ increase. Only FPZ003A and FPZO05A exhibited a decrease in average water elevation. The standard deviation, which is an indicator of the variability of the elevation, was considerably higher in 1998 than in the pre-operational period for most F-Area piezometers. The maximum increase was observed in FPZO05A, where the standard deviation was eleven times the pre-operational level. On the average, the standard deviation for
F-Area piezometers in 1998 was 2.85 times the pre-operational level. Only FPZ001A and FPZ006A exhibited a decrease in standard deviation.

For the H-Area " $A$ " series piezometers, maximum water levels were higher in 1998 than in the pre-operational period. Minimum levels decreased in most of the piezometers, but increased in HPZ003A and HPZ006A. The average water level decreased in piezometers HPZO01A, HPZ004A, and HPZO05A, and increased in HPZ002A, HPZ003A and HPZ006A. The largest change in average elevation occurred in HPZ004A, with a drop of more than three feet compared with preoperational levels. The average change in the average water elevation was a 0.32 foot decrease. The standard deviation was considerably higher in 1998 than in the preoperational period for most H-Area piezometers. The maximum increase was observed in HPZ004A, where the standard deviation was fifty times the pre-operational level. On the average, the standard deviation for H-Area piezometers in 1998 was ten times the preoperational level. Only HPZ003A exhibited a decrease in standard deviation.

Table 8 compares statistics from the entire operational period with the pre-operational values. All piezometer data recorded since the WTUs started to operate was used for this comparison. For F Area, the operational period began in April 1997. For $H$ Area, the operational period began in July 1997 (WSRC 1997a, WSRC 1998b).

Maximum and minimum water elevations were higher in F-Area " $A$ " series piezometers after the WTUs began operations than in the preoperational period. The average water elevation at the piezometers also increased slightly, in general, though FPZ003A and FPZ005A exhibited lower average elevations in the operational period. The largest change in average elevation occurred in FPZO02A, with a rise of $0.49 \mathrm{ft}$ compared with pre-operational elevations. The average change in the average water elevation was a $0.10 \mathrm{ft}$ increase. The standard deviation was considerably higher in 
operational period than in the pre-operational period for most F-Area piezometers. An increase in standard deviation would be expected because of the variations introduced by sporadic operation of the WTUs. The maximum increase was observed in FPZO05A, where the operational standard deviation was nine times the pre-operational level. On the average, the standard deviation has approximately tripled for F-Area piezometers since the WTUs began operating. Only FPZ001A exhibited a decrease in standard deviation.

Maximum water elevations in H-Area " $A$ " series piezometers were higher after the WTUs began operations than in the pre-operational period. Minimum waster elevations decreased except at HPZ003A and HPZ006A. The average water elevation at the piezometers decreased in HPZO01A, HPZO04A and HPZ005A, and increased in HPZ002A, HPZ003A and HPZ006A. The largest change in average elevation occurred in HPZO04A, with a drop of more than two feet compared with preoperational elevations. The average change in average water elevation was a $0.22 \mathrm{ft}$ decrease. The standard deviation was considerably higher in operational period than in the pre-operational period for most H-Area piezometers. The maximum increase was observed again in HPZ004A, where the operational standard deviation was approximately 47 times the preoperational level. On the average, the standard deviation rose to nine times the pre-operational level. Only HPZ003A exhibited a decrease in standard deviation.

Hydrographs for each $\mathrm{F}$ - and $\mathrm{H}$-Area piezometer location were created from the monthly measurements and are presented in Figures 4 through 17. Hydrographs for the reference locations are shown in Figures 18 through 20. Hydrographs of the groundwater elevations based on the data logger measurements are shown in Figures 21 through 34 . The latter set of figures shows groundwater elevation responses to rainfall and evapotranspiration. Each piezometer is discussed individually below.
Groundwater elevation at piezometer FPZ001A (Figure 21) varied by less than $0.5 \mathrm{ft}$ over the entire monitoring period. The location was alternately wet and dry throughout 1996 and 1997. However, FPZ001A was wet throughout 1998, with the groundwater elevation near 198 $\mathrm{ft}$ compared to the ground elevation of $197.90 \mathrm{ft}$. The monthly measurements recorded during the period when the data logger was not functioning were consistent with the data logger measurements from the rest of the monitoring period. The average water elevation in 1998 was $0.13 \mathrm{ft}$ higher than during the preoperational period (Table 7). Diumal variations were slightly bigger during the summer months than during the cooler months.

Groundwater elevation at location FPZ002A (Figure 22) exhibited greater variation than at FPZO01A (Figure 21). Diumal variations were larger during the summer months, approximately May through September. Peaks coincide with periods of rainfall. Groundwater was below ground level for most of 1997, with some wet periods of up to a few weeks. However, the location was wet for all of 1998, with the piezometric surface exceeding ground levels. The average water elevation in 1998 was $1.04 \mathrm{ft}$ higher than during the pre-operational period (Table 7).

Groundwater elevations (Figures 6 and 23) at FPZ003A were measured only by electric tape until August 1998, when a Troll data logger was installed. Utilizing all the measurements, the groundwater elevation at FPZO03A appears to have varied by nearly six feet. The average water elevation recorded during the monthly measurements in 1998 was $188.69 \mathrm{ft}$. The average recorded by data logger during the latter part of 1998 was $187.84 \mathrm{ft}$, while the monthly measurements for the same period averaged $187.37 \mathrm{ft}$. In general, then, the average elevation in 1998 was between $0.18 \mathrm{ft}$ to $1.5 \mathrm{ft}$ lower than the average elevation calculated from the pre-operational period (Table 7). Groundwater remained below ground level throughout the monitoring period.

FPZ004A (Figure 24) is the highest of the FArea piezometer locations $(203.10 \mathrm{ft} \mathrm{msl}$ ) and is 
the location closest to F-Area extraction wells. In general, the water level patterns were similar for FPZ004A and FPZ002A. The groundwater elevation remained below ground level through all three years. During the period when the data logger was not recording, electric tape measurements were consistent with data logger measurements before and after that period. Groundwater levels at FPZ004A exhibited less change during the period from April to June of 1998, when the F-Area WTU extraction wells were not operating, than during the rest of that year or during the same period in 1997. Diumal variations were larger during the late summer months in 1998, after the extraction wells began operating again. The average water elevation in 1998 was $0.69 \mathrm{ft}$ higher than during the preoperational period (Table 7).

Groundwater elevation at FPZ005A (Figure 25) varied by less than seven inches from July 1996 (when measurements began) to June 1998. Groundwater elevation did not show much seasonal or diurnal change during that time. From mid-July through October 1998, groundwater elevation changes were more dramatic. Diurnal variations become more apparent. The average water elevation in 1998 was $0.27 \mathrm{ft}$ lower than during the preoperational period (Table 7).

The piezometric surface at FPZ005B (Figure 8 and Table 6) showed less variation than at FPZO05A. Measurements at FPZO05B generally followed the pattern of increases and decreases seen in FPZ005A, but were sometimes higher than and sometimes lower than the values measured in the deeper piezometer (FPZ005A). In locations with multiple layers of soil, it is not uncommon to find that the piezometric surface measured in a lower layer is actually higher than the piezometric surface measured in an upper layer. In this type of situation, the lower layer has a greater hydraulic head than the upper layer, resulting in an upward gradient in the groundwater.

FPZ006A (Figure 26) is the lowest of the FArea piezometer locations (ground elevation $189.40 \mathrm{ft} \mathrm{msl}$ ). Groundwater elevation changes recorded during the period July 1998 to December 1998 were markedly smaller than during the rest of the monitoring period. In general, water levels appear to be higher in 1998 than in previous years. However, the long period from February 1998 to the first half of July 1998, when the data logger was not functioning due to animal damage, makes this determination difficult. During this period, monthly measurements ranged from $189.14 \mathrm{ft}$ to 189.79 $\mathrm{ft}$, slightly lower than elevations measured just before the data logger began to malfunction. The average water elevation in 1998 was $0.68 \mathrm{ft}$ higher than during the pre-operational period (Table 7).

Measurements at FPZ006B closely followed the pattern of increases and decreases seen in FPZ006A (Figure 9). The piezometric surface measured at FPZ006B remained below the piezometric surface measured at FPZO06A in spite of the fact that FPZO06B is located in a shallower layer of soil. Again, this phenomenon could be explained by a greater hydraulic head in the lower layer of soil.

Groundwater elevations (Figures 10 and 27) at FPZ007A were measured only by electric tape until August 1998, when a Troll data logger was installed. Utilizing all the measurements, the groundwater elevation at FPZ007A appears to have varied by 1.5 feet. The average water elevation recorded during the monthly measurements in 1998 was $193.09 \mathrm{ft}$. The average recorded by data logger during the latter part of 1998 was $192.38 \mathrm{ft}$, while the monthly measurements for the same period averaged $192.92 \mathrm{ft}$. In general, then, the average elevation in 1998 was between $0.18 \mathrm{ft}$ to $0.28 \mathrm{ft}$ lower than the average elevation calculated from the pre-operational period (Table 7). Groundwater elevation at FPZ007A remained below ground elevation throughout the monitoring period.

The piezometric surface at FPZ007B (Figure 10) remained below ground elevation throughout the monitoring period, except in October 1998. Measurements at FPZ007B generally followed the pattern of increases and decreases seen in FPZ007A, but exhibited less variation. 
Groundwater elevations (Figures 11 and 28) at FPZO08A were measured only by electric tape until August 1998, when a Troll data logger was installed. Utilizing all the measurements, the groundwater elevation at FPZ008A appears to have varied by only one foot. The average water elevation recorded during the monthly measurements in 1998 was $187.67 \mathrm{ft}$. The average recorded by data logger during the latter part of 1998 was $186.91 \mathrm{ft}$, while the monthly measurements for the same period averaged $187.62 \mathrm{ft}$. In general, then, the average elevation in 1998 was between $0.04 \mathrm{ft}$ higher to $0.72 \mathrm{ft}$ lower than the average elevation from the preoperational period (Table 7).

Measurements at FPZ008B generally followed the pattern of increases and decreases seen in FPZ008A, but were sometimes higher than and sometimes lower than the values measured in the deeper piezometer (FPZ008A).

Groundwater elevations at HPZ001A (Figures 12 and 29) were measured only by electric tape until August 1998, when a Troll data logger was installed. Utilizing all the measurements, the groundwater elevation at HPZ001A appears to have varied by approximately $2.3 \mathrm{ft}$. The average water elevation recorded during the monthly measurements in 1998 was $202.17 \mathrm{ft}$. The average recorded by data logger during the latter part of 1998 was $203.93 \mathrm{ft}$, while the monthly measurements for the same period averaged $202.08 \mathrm{ft}$. In general, then, the average elevation in 1998 was between $0.14 \mathrm{ft}$ lower to $1.63 \mathrm{ft}$ higher than the average elevation from the pre-operational period (Table 7).

HPZ002A (Figure 30) is located at the highest elevation of all the $\mathrm{H}$ Area piezometers and is close to extraction wells HEX17R, HEX12, HEX 13, HEX 14, HEX 15, HEX I and HEX 2. Groundwater elevation at HPZ002A remained below ground elevation from August 1996 to November 1997. Groundwater elevation exceeded ground level for December 1997 and most of the first half of 1998, then dropped below ground level the latter half of 1998 . The average water elevation in 1998 was $0.34 \mathrm{ft}$ higher than during the pre-operational period (Table 7). The average groundwater elevation from before and after the WTUs began operating varied by less than $0.1 \mathrm{ft}$.

The hydrograph for HPZO02A (Figure 30) shows an apparent change in pattern beginning as early as 1997. Until that time, diumal changes and response to rainfall look similar to other locations. However, beginning in July 1997. changes in the groundwater elevation appear to be larger and more rapid. Sudden increases in levels were often not associated with rainfall. Rapid cycling of increases and decreases in groundwater elevation were evident in July, September, October and December 1997, March 1998, the period from June 1998 to October 1998 and December 1998. This cycling gives the hydrograph for HPZ002A a different appearance than in any other location.

Comparing these dates to the monthly pumping records for the extraction wells (Table 4) reveals a potential correlation. Of the wells listed above, only HEX-1, HEX-2, HEX-12 and HEX17 were operated in 1997 and/or 1998.Pumping of the nearby extraction wells began in July 1997, a month when some rapid cycling of water levels can be seen. The extraction wells were not pumped in August, a month with a normal looking groundwater pattern. The extraction wells were operated from September through December 1997, though -only a small amount of water was extracted; similarly, rapid cycling of the groundwater elevation was observed in September, October and December 1997. Only a small amount of groundwater was extracted from the nearby wells in January and February, 1998, a period with relatively natural variations in groundwater elevations. Extraction volumes increased in March and decreased again in April, with corresponding changes in the groundwater pattern. No water was pumped in May, another month with relatively natural variations in groundwater elevations. The extraction wells operated again from June through December 1998, with only a small amount of water being extracted in November, the only month during that period with relatively natural variations in groundwater elevations. However, the WTU did not appear to cause major changes in the average water elevation. 
HPZO03A (Figure 31) is located farther from the extraction wells than other H-Area locations. The hydrograph for location HPZ003A appears smoother than other locations. Groundwater here was not subject to the rapid changes in elevation seen elsewhere. Hand measurements of the groundwater elevation taken during periods without continuous measurements were 201.39, 201.13 and 201.23 ft respectively (Figure 14). These elevations were consistent with data logger measurements for other months. HPZ003A groundwater elevations exceeded the ground elevation for the most of the monitoring period. The average water elevation in 1998 was $0.55 \mathrm{ft}$ higher than during the pre-operational period (Table 7).

The piezometric surface measured at HPZO03B (Figure 14) remained above ground elevation throughout the monitoring period, except in June 1998. Measurements at HPZ003B generally followed the pattem of increases and decreases seen in HPZ003A. The piezometric surface at HPZ003A, the deeper piezometer, was generally higher than that at HPZ003B.

Location HPZO04A (Figure 32) is close to extraction wells HEX-3 and HEX-4. Groundwater elevations recorded by the data loggers at HPZO04A exhibited the greatest variation of any of the piezometers. As a result, the hydrograph shown in Figure 25 was generated using a different vertical scale than used for the other hydrographs. For the period from the onset of monitoring (August 1996) to December 1997, there was little variation in the groundwater level. During this period, groundwater elevation remained around $210 \mathrm{ft}$. During May and June of 1997, continuous measurements were not available, but hand measurements of $209.76 \mathrm{ft}$ and $210.08 \mathrm{ft}$ were recorded. These hand measurements were consistent with measurements recorded by the data logger before and after this period. In December 1997, the data loggers recorded a rapid drop of about five feet in groundwater elevation. From December 1997 through May 1998, rapid and large variations in the groundwater level were recorded at this site. Changes of nearly 20 feet within a 24 hour period and greater than 14 feet in a one hour period were recorded. From June to December 1998, the changes were much smaller, in general, and the groundwater level gradually rose again to approximately the $210 \mathrm{ft}$ level. Rapid peaks and declines in the elevation were recorded in August and November of 1998. The average water elevation in 1998 was $3.1 \mathrm{ft}$ lower than during the pre-operational period (Table 7) as a result of the low elevations recorded in the first half of the year. However, the average water elevation during the second half of 1998 was $209.52 \mathrm{ft}$, less than one foot lower than in the pre-operational period.

Changes of this magnitude seen in HPZ004A between December 1997 and June 1998 are likely to be due to instrument error rather than actual changes in the piezometric head. The available $\mathrm{F}$ - and H-Area extraction well data (Table 4) is not extensive enough to determine any correlation with the unstable groundwater levels recorded during this period. Without daily WTU operation information, a correlation between the recorded groundwater elevations and operation of the WTUs cannot be ruled out, however. Repeated start-up and shut-down of the extraction system could partially explain the water level changes. However, monthly electric tape measurements during this period (Figure 15) do not corroborate the data logger measurements, instead indicating that the water levels may have remained near the 210 foot level. It is probable that the data logger was not functioning properly during this period.

HPZ005A (Figure 33) is close to extraction wells HEX-3 and HEX-4. Groundwater elevation at HPZ005A remained below ground elevation for the entire monitoring period. Hand measurements of the groundwater levels during those periods in which the data logger was not functioning were consistent with the data logger measurements on either end of the malfunctioning periods. The average water elevation in 1998 was $0.13 \mathrm{ft}$ lower than during the pre-operational period (Table 7).

The piezometric surface measured at HPZ005B (Figure 14) remained below ground elevation throughout the monitoring period, except in 
August 1997. Measurements at HPZOOSB were very similar to those in HPZ005A.

Groundwater elevations (Figures 17 and 34) at HPZ006A were measured only by electric tape until August 1998, when a Troll data logger was installed. Utilizing all the measurements, the groundwater elevation at HPZ,001A appeared to vary by approximately $2.2 \mathrm{ft}$. The average water elevation recorded during the monthly measurements in 1998 was $202.87 \mathrm{ft}$. The average water level calculated from data logger measurements during the latter part of 1998 was $202.73 \mathrm{ft}$, while the monthly measurements for the same period averaged $202.55 \mathrm{ft}$. In general, then, the average elevation in 1998 was between $0.58 \mathrm{ft}$ to $0.86 \mathrm{ft}$ higher than the average elevation calculated from the pre-operational period (Table 7). Groundwater elevation in HPZ006A remained above ground elevation throughout the monitoring period, except for the elevation measured by electric tape in May 1996.

Groundwater elevations have been measured monthly at the reference locations FHR001, FHR002 and FHR003 (Figures 18, 19 and 20) since July 1997. The pattern of groundwater elevation changes was nearly identical for FHR001 and FHR002 except for the scale; groundwater elevations ranged more than seven feet at FHR002, but only approximately three feet at FHR001. The standard deviation of groundwater elevation measurements calculated at FHR002 (Table 6) was the highest of all the piezometer locations except HPZ004A (when calculated from the data logger measurements). At all three reference locations, groundwater elevations peaked between January and June 1998. As would be expected, rainfall during this period was greater than during the latter half of 1998. Rainfall during the first half of 1998 accounted for $63 \%$ of the total rainfall in F Area and $65 \%$ of the total rainfall in $\mathrm{H}$ Area for 1998.

Similar groundwater elevation peaks in the first half of 1998 were evident in other piezometers. The peaks were observed clearly for FPZ002A (Figure 22), FPZO04A (Figure 24), FPZ005A (Figure 25), FPZ006A (Figure 9), HPZ002A (Figure 30), and HPZO04A (Figure 15). Peaks in the first half of 1998 were observed to a lesser degree at HPZO03A (Figure 31) and HPZ005A (Figure 33). For FPZ003A, FPZ007A, FPZO08A, and HPZ001A, in which groundwater was measured only monthly during the first half of 1998, the hydrographs in Figures 6,10 and 11 also show peaks in elevation during that period. In contrast with the majority of the piezometers, groundwater at HPZ006A actually peaks during the latter half of 1998. The fact that most F-and H-Area piezometers recorded piezometric changes similar to those in the reference locations might indicate that the rise in groundwater levels during this period could be simply the result of natural causes and not a result of the operation of the WTUs.

However, during the first half of 1998 , the WTU extraction wells were pumping less groundwater than during the second half of 1998. Without daily WTU operation information, a correlation between the recorded groundwater elevations and operation of the WTUs cannot be ruled out.

Data collected from the continuous monitoring effort has confirmed the expected correlation between rainfall events and groundwater elevations. Figure 35 represents a typical plot of data collected from the piezometers. In general, groundwater elevation rises rapidly after a rainfall, then declines more slowly. From this figure, it can be seen that the response to rainfall was immediate as well as transient. However, more detailed study is needed to understand the magnitude and duration of the transient surge in water levels associated with rainfall.

Diurnal fluctuations in water level due to evapotranspiration are clearly shown in Figure 36. A periodic decline in water levels was observed during the middle portions of each day, which may be attributed to increased evapotranspiration demand. During the nighttime hours when evapotranspiration demands are lowest, the water levels recover. As seen in Figure 36, fluctuations of $0.1 \mathrm{ft}$ were common during peak evapotranspiration periods. Diumal changes were greater in the warmer months than in the cooler months. 


\section{Conclusions}

The operation of the WTUs in the $F$ and $H$ Areas of SRS has the potential to lower the groundwater level near the extraction wells, potentially affecting the wetland system between the former F- and H-Area seepage basins and Fourmile Branch. However, the changes in the piezometer water elevations measured in 1998 were generally small and are expected to have had insignificant effects at this time on the wetlands (Nelson 1999). For most of the piezometers installed near the $F_{-}$and $H$-Area seeplines, groundwater levels actually increased after the WTUs began operating. These increases may be a result of increased rainfall in the operational period (an average of 4.8 inches per month for F Area and 5.0 inches per month for $\mathrm{H}$ Area) compared to the pre-operational period (an average of 3.9 inches per month for both areas). Sufficient information was not available to determine any correlation between the groundwater elevation increases and operation of the extraction and injection wells. Elevation trends seen in 1998 may be very different in 1999 and future years.

Overall, the average change in the 1998 water elevations, compared to the pre-operational period elevations, was a $0.28 \mathrm{ft}$ increase for $F-$ Area piezometers and a 0.32 foot decrease for $\mathrm{H}$-Area piezometers. Excluding the questionable data associated with HPZO04A, the greatest decrease in average groundwater elevation in 1998 was seen in FPZO05A, with a decrease of $0.27 \mathrm{ft}(3.2 \mathrm{in})$ from pre-operational levels. The maximum increase in average elevation in 1998 was seen in FPZ002A, which increased $1.04 \mathrm{ft}$ from the pre-operational level.

Comparing statistics from the entire operational period with the pre-operational values yields similar results. The average change was a $0.10 \mathrm{ft}$ increase for F-Area piezometers and a $0.22 \mathrm{ft}$ decrease for $\mathrm{H}$-Area piezometers. Excluding the questionable data associated with HPZ004A, the greatest decrease in average groundwater elevation in the operational period was seen in FPZ003A, closely followed by HPZ005A. Groundwater elevations at FPZ003A and
HPZO05A decreased only $0.17 \mathrm{ft}(2 \mathrm{in})$ and 0.16 ft (1.9 in), respectively, from pre-operational levels. The maximum increase in average elevation was seen in FPZO02A, which increased $0.49 \mathrm{ft}(5.9 \mathrm{in})$ from the preoperational level. HPZ006A and HPZ003A followed closely with increases of $0.48 \mathrm{ft}(5.8$ in) and $0.46 \mathrm{ft}(5.5 \mathrm{in})$, respectively.

During 1998, as well as entire operational period, most piezometers measured greater fluctuations in groundwater elevations than in the pre-operational period. Excluding the questionable data at HPZO04A, maximum and minimum elevations were as much as $2.13 \mathrm{ft}$ higher and $1.54 \mathrm{ft}$ lower, respectively, than in the pre-operational period.

The only information available on the pumping schedule for the WTU extraction wells at the time of this report was the total monthly volumes pumped from each extraction well. From these data, it can be inferred that the WTUs were not operating steadily or at full capacity in 1998. Thus, water elevation changes measured in 1998 may not accurately represent the changes that can be expected in the future. Without a more detailed breakdown, including system start-up and shut-down times and dates, plus extraction rates and volumes during each operating period, few conclusions can be drawn on the relative importance of rainfall versus the WTUs on groundwater elevations along the seeplines.

\section{References}

Dixon, K. L. 1995. Inter-Office Memorandum, "Re: Revised Proposal for Monitoring Water Levels in the F- and H-Area Wetlands," SRTESS-95-0340.

Dixon, K. L. 1996. Monitoring of the Water Levels in the Wetlands of Fourmile Branch Near the F- and H-Areas of SRS. WSRC-TR-960289. Westinghouse Savannah River Company, Sayannah River Technology Center, Aiken SC.

Dixon, K. L., V. A. Rogers, and B. B. Looney, 1993. Results of the quarterly tritium survey of Four Mile Creek and its seeplines in the F- and 
H- Areas of SRS: September 1993. WSRC-TR93-286-ESS, Rev. 1, Westinghouse Savannah River Company, Savannah River Technology Center, Aiken SC.

Dixon, K. L. and V. A. Rogers. 1993. Semiannual sampling of Fourmile Branch and its seeplines in the F- and H-Areas of SRS: July 1992. WSRC-TR-93-289, Westinghouse Savannah River Company, Savannah River Technology Center, Aiken SC.

Dixon, K. L., V. A. Rogers, and B. B. Looney. 1994. Results of the Quarterly Tritium Survey of Fourmile Branch and its Seeplines in the Fand H-Areas of SRS: September 1993. WSRCTR-94-0286, Westinghouse Savannah River Company, Savannah River Technology Center, Aiken, SC.

Haselow, J. S., M. Harris, B. B. Looney, N. V. Halverson, and J. B. Gladden. 1990. Analysis of soil and water at the Four Mile Creek seepline near the F- and H-Areas of SRS. WSRC-RP-900591, Westinghouse Savannah River Company, Savannah River Technology Center, Aiken SC.

Hunter, C. 1999. Inter-Office Memorandum to N. V. Halverson, dated May 29, transmitting raw data on rainfall at F- and H-Area from 1996 through 1998. Westinghouse Savannah River Company, Savannah River Technology Center, Aiken, SC.

Killian, T.H., N.L. Kolb, P. Corbo, and I.W. Marine. 1985a. F-Area seepage basins. DPST85-704, E.I. du Pont de Nemours and Company, Savannah River Laboratory, Aiken, SC.

Killian, T.H., N.L. Kolb, P. Corbo, and I.W. Marine. 1985b. H-Area seepage basins. DPST85-706, E.I. du Pont de Nemours and Company, Savannah River Laboratory, Aiken, SC.

Nelson, E. A. 1999. Personal communication with N. V. Halverson, June 24. Westinghouse Savannah River Company, Savannah River Technology Center, Aiken, SC.

WSRC 1997a. F-Area Hazardous Waste Management Facility Corrective Action Report, First and Second Quarters 1997, Volume I"
WSRC-TR-97-0216. Westinghouse Savannah River Company, Aiken, SC

WSRC 1997b. H-Area Hazardous Waste Management Facility Corrective Action Report, First and Second Quarters 1997, Volume I" WSRC-TR-97-0240. Westinghouse Savannah River Company, Aiken, SC

WSRC 1998a. F-Area Hazardous Waste Management Facility Corrective Action Report, Third and Fourth Quarters 1997, Volume I" WSRC-TR-98-00003. Westinghouse Savannah River Company, Aiken, SC

WSRC 1998b. F-Area Hazardous Waste Management Facility Corrective Action Report, First and Second Quarters 1998, Volume I" WSRC-TR-98-00147. Westinghouse Savannah River Company, Aiken, SC

WSRC 1998c. H-Area Hazardous Waste Management Facility Corrective Action Report, Third and Fourth Quarters 1997, Volume I" WSRC-TR-98-00004. Westinghouse Savannah River Company, Aiken, SC

WSRC 1998d. H-Area Hazardous Waste Management Facility Corrective Action Report, First and Second Quarters 1998, Volume I" WSRC-TR-98-00147. Westinghouse Savannah River Company, Aiken, SC

WSRC 1999a. F-Area Hazardous Waste Management Facility Corrective Action Report, Third and Fourth Quarters 1998, Volume I" WSRC-TR-99-00012. Westinghouse Savannah River Company, Aiken, SC

WSRC 1999b. H-Area Hazardous Waste Management Facility Corrective Action Report, Third and Fourth Quarters 1998, Volume I" WSRC-TR-99-00013. Westinghouse Savannah River Company, Aiken, SC 


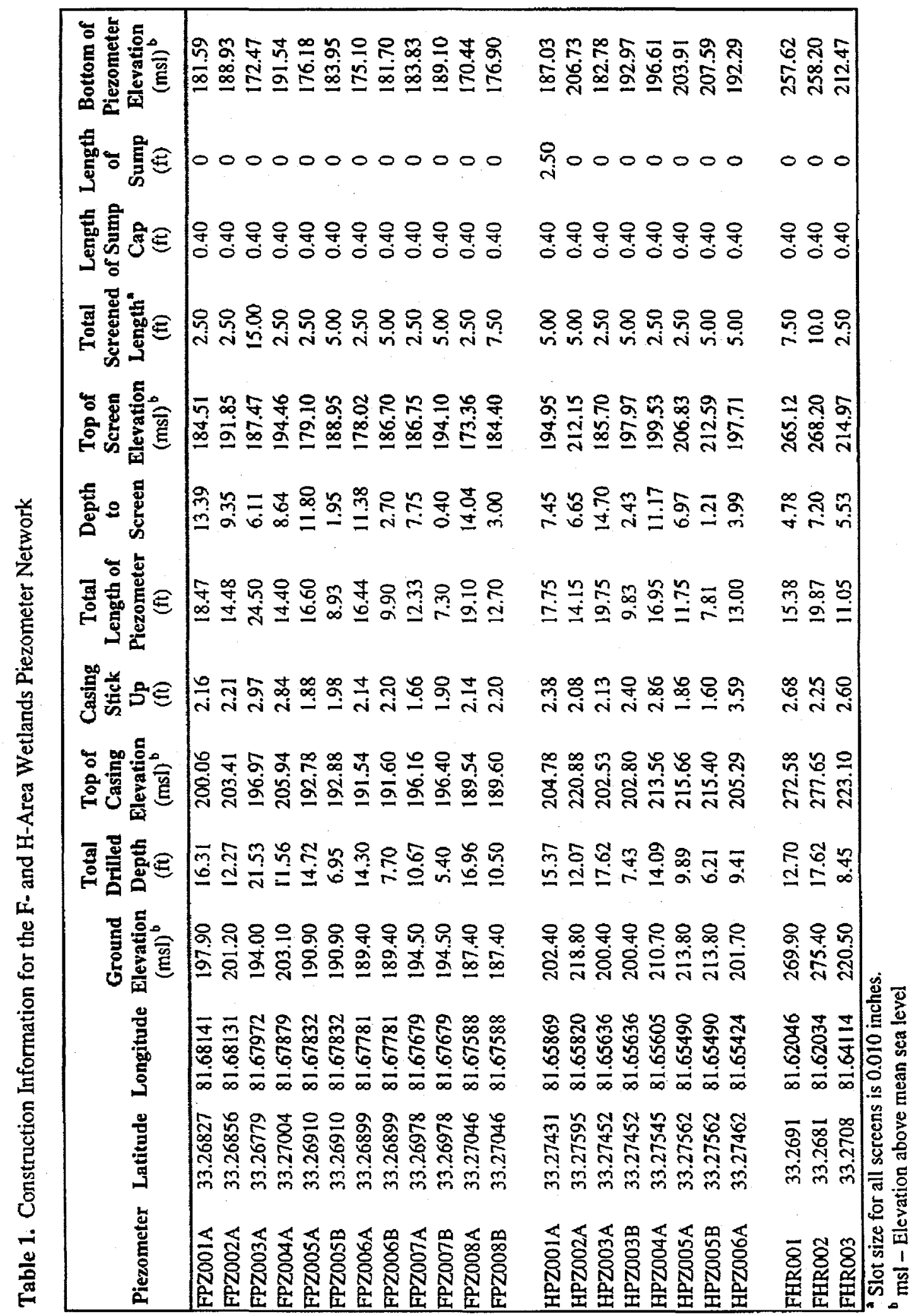


Table 2. Piezometers with data logging equipment installed

\begin{tabular}{|llll|}
\hline Piezometer & Latitude & Longitude & $\begin{array}{l}\text { Instrument Installation } \\
\text { Date }\end{array}$ \\
\hline FPZ001A & 33.26827 & 81.68141 & September 1996 \\
FPZ002A & 33.26856 & 81.68131 & September 1996 \\
FPZ003A & 33.26779 & 81.67972 & August 1998 \\
FPZ004A & 33.27004 & 81.67879 & July 1996 \\
FPZ005A & 33.26910 & 81.67832 & July 1996 \\
FPZ006A & 33.26899 & 81.67781 & July 1996 \\
FPZO07A & 33.26978 & 81.67679 & August 1998 \\
FPZO08A & 33.27046 & 81.67588 & August 1998 \\
HPZ001A & 33.27431 & 81.65869 & August 1998 \\
HPZ002A & 33.27595 & 81.65820 & September 1996 \\
HPZ003A & 33.27452 & 81.65636 & August 1996 \\
HPZ004A & 33.27545 & 81.65605 & August 1996 \\
HPZ005A & 33.27562 & 81.65490 & September 1996 \\
HPZ006A & 33.27462 & 81.65424 & August 1998 \\
\hline
\end{tabular}


Table 3. Groundwater Extraction (Thousands of Gallons) by the F-Area Groundwater Remediation Waste Treatment Unit, $1997-1998$

\begin{tabular}{|c|c|c|c|c|c|c|c|c|c|c|c|c|}
\hline $\begin{array}{l}\text { Well } \\
\text { ID }\end{array}$ & Jan & Feb & Mar & Apr & May & Jun & Jul & Aug & Sep & Oct & Nov & Dec \\
\hline \multicolumn{13}{|l|}{1997} \\
\hline FEX-1 & 0 & 0 & 0 & 0.7 & 2 & 2 & 4 & 39 & 18 & 23 & 19 & 54 \\
\hline FEX-2 & 0 & 0 & 0 & 0.6 & 2 & 2 & 4 & 38 & 17 & 22 & 18 & 51 \\
\hline FEX-3 & 0 & 0 & 0 & 1 & 3 & 3 & 4 & 42 & 19 & 24 & 16 & 57 \\
\hline FEX-4 & 0 & 0 & 0 & 1 & 3 & 3 & 4 & 42 & 20 & 24 & 15 & 58 \\
\hline FEX-5 & 0 & 0 & 0 & 0.3 & 0.9 & 0.9 & 2 & 19 & 9 & 11 & 11 & 26 \\
\hline FEX-6 & 0 & 0 & 0 & 1 & 3 & 3 & 3 & 33 & 15 & 18 & 14 & 45 \\
\hline FEX-7 & 0 & 0 & 0 & 0.7 & 2 & 2 & 3 & 34 & 16 & 19 & 13 & 47 \\
\hline FEX-8 & 0 & 0 & 0 & 0.4 & 1 & 1 & 3 & 27 & 13 & 16 & 16 & 37 \\
\hline FEX-9 & 0 & 0 & 0 & 0.6 & 2 & 2 & 3 & 33 & 15 & 18 & 12 & 44 \\
\hline FEX-10 & 0 & 0 & 0 & 2 & 5 & 5 & 5 & 49 & 22 & 28 & 19 & 66 \\
\hline FEX-11 & 0 & 0 & 0 & 2 & 5 & 5 & 5 & 55 & 25 & 32 & 20 & 75 \\
\hline TOTAL & 0 & 0 & 0 & 10 & 30 & 30 & 40 & 412 & 190 & 235 & 173 & 560 \\
\hline \multicolumn{13}{|l|}{1998} \\
\hline FEX-1 & 0 & 20 & 33 & 0 & 0 & 0 & 49 & 332 & 222 & 451 & 136 & 123 \\
\hline FEX-2 & 30 & 81 & 30 & 0 & 0 & 0 & 165 & 397 & 216 & 272 & 276 & 162 \\
\hline FEX-3 & 0 & 0 & 42 & 0 & 0 & 0 & 177 & 434 & 275 & 282 & 157 & 154 \\
\hline FEX-4 & 159 & 82 & 39 & 0 & 0 & 0 & 115 & 331 & 268 & 275 & 154 & 155 \\
\hline FEX-5 & 42 & 0.2 & 29 & 0 & 0 & 0 & 41 & 102 & 177 & 186 & 98 & 102 \\
\hline FEX-6 & 128 & 88 & 38 & 0 & 0 & 0 & 152 & 315 & 196 & 258 & 163 & 159 \\
\hline FEX-7 & 117 & 87 & 35 & 0 & 0 & 0 & 103 & 307 & 203 & 310 & 154 & 123 \\
\hline FEX-8 & 25 & 55 & 29 & 0 & 0 & 0 & 70 & 205 & 184 & 296 & 131 & 110 \\
\hline FEX-9 & 2 & 39 & 31 & 0 & 0 & 0 & 16 & 221 & 190 & 138 & 157 & 85 \\
\hline FEX-10 & 0 & 95 & 42 & 0 & 0 & 0 & 128 & 414 & 255 & 379 & 124 & 0 \\
\hline FEX-11 & 67 & 0 & 42 & 0 & 0 & 0 & 198 & 410 & 262 & 290 & 130 & 0 \\
\hline TOTAL & 570 & 547 & 390 & 0 & 0 & 0 & 1213 & 3470 & 2447 & 3135 & 1679 & 1172 \\
\hline
\end{tabular}

Sources: WSRC 1997a, WSRC 1998a, WSRC 1998b, WSRC 1999a 
Table 4. Groundwater Extraction (Thousands of Gallons) by the H-Area Groundwater Remediation Waste Treatment Unit , 1997 - 1998

\begin{tabular}{|l|cccccccccccc|}
\hline Well & Jan & Feb & Mar & Apr & May & Jun & Jul & Aug & Sep & Oct & Nov & Dec \\
\hline ID & & & & & & & & & & & & \\
\hline HE9 & & & & & & & & & & & & \\
HEX-1 & 0 & 0 & 0 & 0 & 0 & 0 & 3 & 0 & 121 & 30 & 5 & 29 \\
HEX-2 & 0 & 0 & 0 & 0 & 0 & 0 & 0 & 0 & 18 & 0.2 & 1 & 19 \\
HEX-3 & 0 & 0 & 0 & 0 & 0 & 0 & 2 & 0 & 87 & 21 & 4 & 22 \\
HEX-9 & 0 & 0 & 0 & 0 & 0 & 0 & 3 & 0 & 108 & 25 & 5 & 32 \\
HEX-12 & 0 & 0 & 0 & 0 & 0 & 0 & 1 & 0 & 43 & 11 & 2 & 9 \\
HEX-16 & 0 & 0 & 0 & 0 & 0 & 0 & 1 & 0 & 24 & 8 & 1 & 0 \\
HEX-17 & 0 & 0 & 0 & 0 & 0 & 0 & 3 & 0 & 112 & 27 & 5 & 27 \\
HEX-18 & 0 & 0 & 0 & 0 & 0 & 0 & 4 & 0 & 147 & 38 & 0 & 33 \\
HEX-19 & 0 & 0 & 0 & 0 & 0 & 0 & 0.4 & 0 & 17 & 4 & 0 & 6 \\
\hline TOTAL & 0 & 0 & 0 & 0 & 0 & 0 & 19 & 0 & 793 & 193 & 24 & 205 \\
\hline 1998 & & & & & & & & & & & & \\
\hline HEX-1 & 27 & 124 & 300 & 48 & 0 & 232 & 34 & 147 & 90 & 186 & 6 & 315 \\
HEX-2 & 0 & 0 & 0 & 0 & 0 & 23 & 0 & 0 & 0 & 0 & 0 & 0 \\
HEX-3 & 21 & 109 & 285 & 45 & 0 & 116 & 320 & 343 & 412 & 442 & 25 & 315 \\
HEX-4 & 27 & 117 & 285 & 50 & 0 & 198 & 273 & 229 & 388 & 300 & 0 & 106 \\
HEX-9 & 14 & 89 & 69 & 37 & 0 & 44 & 186 & 101 & 263 & 119 & 6 & 172 \\
HEX-12 & 0.8 & 0 & 78 & 18 & 0 & 48 & 170 & 132 & 192 & 111 & 12 & 141 \\
HEX-16 & 26 & 116 & 291 & 0 & 0 & 141 & 368 & 264 & 399 & 498 & 7 & 183 \\
HEX-17 & 3 & 0 & 189 & 48 & 0 & 143 & 491 & 332 & 577 & 527 & 7 & 497 \\
HEX-18 & 0 & 0 & 388 & 52 & 0 & 235 & 143 & 147 & 0 & 0 & 17 & 310 \\
HEX-19 & 14 & 43 & 45 & 14 & 0 & 47 & 157 & 110 & 173 & 115 & 10 & 39 \\
\hline TOTAL & 133 & 599 & 1930 & 313 & 0 & 1227 & 2141 & 1806 & 2493 & 2298 & 90 & 2077 \\
\hline
\end{tabular}

Sources: WSRC 1997b, WSRC 1998c, WSRC 1998d, WSRC 1999b 
Table 5. Water Levels Measured by Electric Water-Level Tape at Individual Piezometers, September 1997 to August 1998

\begin{tabular}{|c|c|c|c|c|c|c|c|c|c|c|c|c|c|}
\hline \multirow[t]{2}{*}{$\begin{array}{c}\text { Piezometer } \\
\text { ID }\end{array}$} & \multirow[b]{2}{*}{ Sep-97 } & \multirow[b]{2}{*}{ Oct-97 } & \multirow[b]{2}{*}{ Nov-97 } & \multirow[b]{2}{*}{ Dec-97 } & \multicolumn{4}{|c|}{$\begin{array}{l}\text { Water Level Elevations } \\
\text { (msl) }\end{array}$} & \multirow[b]{2}{*}{ May-98 } & \multirow[b]{2}{*}{ June-98 } & \multirow[b]{2}{*}{ July-98 } & \multirow[b]{2}{*}{ Aug-98 } & \multirow[t]{2}{*}{$\begin{array}{l}\text { Ground } \\
\text { Elevation } \\
\text { (msl) }\end{array}$} \\
\hline & & & & & Jan-98 & Feb-98 & Mar-98 & Apr -98 & & & & & \\
\hline FP7001A & 197.88 & 197.96 & 197.96 & 197.91 & 198.06 & 198.06 & 198.06 & 198.06 & 198.06 & 198.06 & 198.06 & 198.01 & 197.90 \\
\hline $\mathrm{FPZOO} 2 \mathrm{~A}$ & 200.56 & 201.11 & 201.01 & 201.31 & 202.21 & 202.51 & 202.71 & 202.69 & 202.51 & 202.27 & 202.08 & 201.73 & 201.20 \\
\hline FPZ $003 A$ & 186.12 & 189.32 & 190.07 & 190.82 & 191.97 & 191.77 & 191.77 & 188.02 & 189.25 & 187.09 & 187.57 & 186.33 & 194.00 \\
\hline FPZO04A & 200.59 & 200.84 & 200.94 & 201.04 & 201.89 & 202.29 & 202.54 & 202.59 & 202.43 & 202.17 & 201.82 & 201.39 & 203.10 \\
\hline FPZO05A & 190.96 & 191.13 & 191.18 & 191.13 & 191.28 & 191.28 & 191.28 & 191.28 & 191.18 & 191.07 & 191.09 & 191.00 & 190.90 \\
\hline FPZ005B & 191.16 & 191.13 & 191.13 & 191.18 & 191.21 & 191.23 & 191.18 & 191.18 & 191.17 & 191.09 & 191,30 & 191.17 & 190.90 \\
\hline FPZO06A & 188.14 & 189.34 & 189.34 & 189.49 & 189.74 & 189.79 & 189.74 & 189.69 & 189.14 & 188.66 & 189.14 & 188.60 & 189.40 \\
\hline FPZ006B & 187.72 & 189.05 & 189.05 & 189.15 & 189.25 & 189.20 & 189.20 & 189.15 & 188.79 & 188.09 & 188.40 & 188.09 & 189.40 \\
\hline FPZ007A & 192.48 & 193.16 & 193.11 & 193.16 & 193.41 & 193.46 & 193.46 & 193.39 & 193.11 & 192.66 & 193.06 & 192.75 & 194.50 \\
\hline FPZ007B & 194.15 & 194.25 & 194.30 & 194.40 & 194.40 & 194.40 & 194.40 & 194.45 & 194.40 & 194.32 & 194.35 & 194.30 & 194.50 \\
\hline FPZOODAA & 187.54 & 187.64 & 187.64 & 187.69 & 187.79 & 187.79 & 187.79 & 187.74 & 187.64 & 187.63 & 187.60 & 187.58 & 187.40 \\
\hline FPZ008B & 187.58 & 187.10 & 187.55 & 187.60 & 187.65 & 187.65 & 187.65 & 187.64 & 187.55 & 187.57 & 187.56 & 187.55 & 187.40 \\
\hline HPZOOLA & 202.08 & 202.68 & 202.28 & 202.28 & 202.28 & 202.28 & 202.33 & 202.38 & 202.19 & 202.04 & 202.16 & 202.05 & 202.40 \\
\hline HPZ002A & 217.08 & 217.78 & 216.98 & 218.28 & 219.23 & 219.48 & 219.43 & 219.57 & 219.47 & 218.37 & 218.27 & 217.67 & 218.80 \\
\hline HPZO03A & 201.08 & 201.53 & 201.53 & 201.58 & 201.73 & 201.93 & 201.93 & 201.93 & 201.58 & 201.23 & 201.53 & 201.53 & 200.40 \\
\hline HPZO03B & 200.65 & 201.05 & 200.95 & 200.90 & 201.00 & 201.00 & 201.00 & 200.99 & 200.53 & 200.19 & 200.43 & 200.57 & 200.40 \\
\hline HPZ004A & 210.06 & 210.26 & 210.26 & 210.31 & 210.36 & 210.36 & 210.36 & 210.37 & 210.21 & 210.14 & 210.05 & 210.02 & 210.70 \\
\hline HPZOOSA & 211.09 & 213.21 & 213.16 & 213.21 & 213.36 & 213.36 & 213.16 & 213.51 & 212.21 & 211.62 & 211.64 & 211.57 & 213.80 \\
\hline HPZ005B & 210.98 & 213.30 & 213.10 & 213.25 & 213.40 & 213.40 & 213.30 & 213.29 & 212.19 & 211.59 & 211.56 & 211.50 & 213.80 \\
\hline HPZ006A & 202.21 & 202.29 & 202.49 & 202.39 & 202.39 & 202.34 & 202.39 & 202.48 & 202.34 & 202.43 & 202.36 & $202: 98$ & 201.70 \\
\hline FHR001 & 267.69 & 268.33 & 268.68 & 269.48 & 270.43 & 270.48 & 270.48 & 270.36 & 269.88 & 269.18 & 268.36 & 268.07 & 269.90 \\
\hline FHR002 & 269.93 & 270.45 & 271.35 & 273.55 & 274.80 & 275.35 & 275.50 & 275.49 & 274.15 & 273.15 & 271.14 & 270.63 & 275.40 \\
\hline FHR003 & 219.84 & 220.00 & 220.00 & 220.00 & 220.15 & 220.20 & 220.20 & 220.65 & 220.15 & 220.02 & 219.95 & 219.99 & 220.50 \\
\hline
\end{tabular}


Table 6. Average, Maximum and Minimum Water Levels Measurements from September 1997 to December 1998

\begin{tabular}{|c|c|c|c|c|c|c|c|c|c|c|}
\hline \multirow[b]{2}{*}{$\begin{array}{c}\text { Piez. } \\
\text { ID }\end{array}$} & \multicolumn{5}{|c|}{. Monthly Hand Measurements } & \multicolumn{5}{|c|}{ Continuous Measurements } \\
\hline & $\begin{array}{l}\text { Min. } \\
\text { Water } \\
\text { Level } \\
\text { (msl) }\end{array}$ & $\begin{array}{l}\text { Max. } \\
\text { Water } \\
\text { Level } \\
\text { (msl) }\end{array}$ & $\begin{array}{l}\text { Avg. } \\
\text { Water } \\
\text { Level } \\
\text { (msl) }\end{array}$ & $\begin{array}{c}\text { Stand. } \\
\text { Dev. } \\
\text { (ft) }\end{array}$ & $\begin{array}{c}\text { Water } \\
\text { Level } \\
\text { Rel. to } \\
\text { Ground } \\
\text { Elev. }{ }^{a} \\
\text { (ft) }\end{array}$ & $\begin{array}{l}\text { Min. } \\
\text { Water } \\
\text { Level } \\
\text { (msl) }\end{array}$ & $\begin{array}{l}\text { Max. } \\
\text { Water } \\
\text { Level } \\
\text { (msl) }\end{array}$ & $\begin{array}{l}\text { Avg. } \\
\text { Water } \\
\text { Level } \\
\text { (msI) }\end{array}$ & $\begin{array}{c}\text { Stand. } \\
\text { Dev. } \\
\text { (ft) }\end{array}$ & $\begin{array}{l}\text { Water } \\
\text { Level } \\
\text { Rel. to } \\
\text { Ground } \\
\text { Elev." } \\
\text { (ft) }\end{array}$ \\
\hline FPZ001A & 197.88 & 198.19 & 198.02 & 0.07 & 0.12 & 197.79 & 198.21 & 19801 & 0.06 & 0.11 \\
\hline FPZ002A & 200.56 & 202.71 & 201.83 & 0.64 & 0.63 & 200.38 & 203.36 & 201.94 & 0.68 & 0.74 \\
\hline FPZO003A & 186.12 & 191.97 & 188.79 & 1.99 & -5.21 & 186.01 & 190.12 & 187.84 & 0.86 & -6.16 \\
\hline FPZ004A & 200.59 & 202.59 & 201.62 & 0.64 & -1.48 & 200.35 & 202.89 & 201.64 & 0.66 & -1.46 \\
\hline FPZ005A & 190.96 & 191.28 & 191.14 & 0.10 & 0.24 & 189.45 & 191.57 & 190.92 & 0.50 & 0.02 \\
\hline FPZO05B & 191.09 & 191.3 & 191.17 & 0.05 & 0.27 & - & - & - & - & - \\
\hline FPZO06A & 188.14 & 190.19 & 189.25 & 0.53 & -0.15 & 187.94 & 192.64 & 189.57 & 0.50 & 0.17 \\
\hline FPZOO6B & 187.72 & 189.88 & 188.84 & 0.54 & -0.56 & - & - & - & - & - \\
\hline FPZ007A & 192.48 & 193.46 & 193.07 & 0.29 & -1.43 & 191.95 & 192.86 & 192.38 & 0.12 & -2.12 \\
\hline FPZ007B & 194.15 & 194.66 & 194.36 & 0.11 & -0.14 & - & - & - & - & - \\
\hline FPZ008A & 187.54 & 187.79 & 187.66 & 0.08 & 0.26 & 186.76 & 187.14 & 186.91 & 0.03 & -0.49 \\
\hline FPZ008B & 187.10 & 187.65 & 187.57 & 0.13 & 0.17 & - & - & - & - & - \\
\hline $\mathrm{HPZOO} 1^{\mathrm{b}} \mathrm{A}$ & 201.87 & 202.68 & 202.21 & 0.18 & -0.19 & 203.44 & 204.13 & 203.93 & 0.08 & 1.53 \\
\hline HPZO02A & 216.88 & 219.57 & 218.18 & 0.98 & -0.62 & 216.39 & 219.74 & 218.19 & 0.83 & -0.61 \\
\hline HPZ003A & 200.58 & 201.93 & 201.48 & 0.36 & 1.08 & 201.07 & 202.18 & 201.68 & 0.23 & 1.28 \\
\hline HPZ003B & 200.19 & 201.98 & 200.87 & 0.39 & 0.47 & - & - & - & $\therefore$ & - \\
\hline HPZOO4A & 210.02 & 211.51 & 210.29 & 0.35 & -0.41 & 197.67 & 218.76 & 207.70 & 3.41 & -3.00 \\
\hline HPZ005A & 211.09 & 213.51 & 212.37 & 0.90 & -1.43 & 210.78 & 213.71 & 212.59 & 0.80 & -1.2 \\
\hline HPZO0SB & 210.98 & 213.40 & 212.44 & 0.87 & .1 .36 & - & $=$ & - & - & - \\
\hline HPZ006 $\mathrm{A}^{b}$ & 202.09 & 202.98 & 202.43 & 0.21 & 0.73 & 202.33 & 204.30 & 202.73 & 0.28 & 1.03 \\
\hline FHROOI & 267.51 & 270.48 & 268.92 & 1.11 & -0.98 & - & - & - & - & - \\
\hline FHR002 & 267.95 & 275.50 & 272.12 & 2.42 & -3.28 & - & - & - & - & - \\
\hline FHR003 & 219.59 & 220.65 & 220.02 & 0.24 & -0.48 & - & - & - & - & - \\
\hline
\end{tabular}

${ }^{2}$ Positive values indicate that the water level was higher than ground level. Negative values indicate that the water level was lower than ground level.

${ }^{b}$ Continuous data for these piezometers represent only 5 months of measurements and were not considered to be representative. 
Table 7. Comparison of the 1998 Piezometer Water-Level Statistics with the Pre-Operation Period ${ }^{a}$

\begin{tabular}{|c|c|c|c|c|c|c|c|c|c|c|c|c|}
\hline Piezometer & $\begin{array}{l}\text { Pre-Op. } \\
\text { Period }^{b}\end{array}$ & Uaximur & Difference ${ }^{c}$ & $\begin{array}{l}\text { Pre-Op. } \\
\text { Period }^{b}\end{array}$ & Minimur & Difference $^{\mathrm{c}}$ & $\begin{array}{l}\text { Pre-Op. } \\
\text { Period }^{\text {b }}\end{array}$ & Averag & Difference & $\begin{array}{l}\text { Stan } \\
\text { Pre-Op. } \\
\text { Period }^{b}\end{array}$ & ard De & Difference $^{c}$ \\
\hline FPZ001A & 198.10 & 198.21 & 0.11 & 197.80 & 197.95 & 0.15 & 197.91 & 198.04 & 0.13 & 0.08 & 0.04 & -0.04 \\
\hline FPZO02A & 201.91 & 203.36 & 1.45 & 200.97 & 201.58 & 0.61 & 201.21 & 202.25 & 1.04 & 0.22 & 0.42 & 0.20 \\
\hline FPZ003A & 191.22 & 191.97 & 0.75 & 187.07 & 186.33 & -0.74 & 188.87 & 188.69 & .0 .18 & 1.18 & 2.05 & 0.87 \\
\hline FPZOOOAA & 202.46 & 202.89 & 0.43 & 200.90 & 200.98 & 0.08 & 201.21 & 201.90 & 0.69 & 0.15 & 0.54 & 0.39 \\
\hline FPZO05A & 191.30 & 191.57 & 0.27 & 190.99 & 189.45 & -1.54 & 191.09 & 190.82 & -0.27 & 0.05 & 0.56 & 0.51 \\
\hline FPZ006A & 189.81 & 191.94 & 2.413 & 188.50 & 189.59 & 1.09 & 189.15 & 189.83 & 0.68 & 0.26 & 0.08 & -0.18 \\
\hline FPZ007A & 193.34 & 193.46 & 0.12 & 192.66 & 192.66 & 0.00 & 193.02 & 193.09 & 0.07 & 0.17 & 0.28 & 0.11 \\
\hline FPZO08A & 187.72 & 187.79 & 0.07 & 187.56 & 187.58 & 0.02 & 187.63 & 187.67 & 0.04 & 0.05 & 0.08 & 0.03 \\
\hline HPZ001A & 202.38 & 202.38 & 0.00 & 202.05 & 201.87 & -0.18 & 202.31 & 202.17 & -0.14 & 0.08 & 0.14 & 0.06 \\
\hline $\mathrm{HPZ} 002 \mathrm{~A}$ & 218.78 & 219.74 & 0.96 & 217.44 & 216.72 & -0.72 & 218.03 & 218.37 & 0.34 & 0.27 & 0.82 & 0.55 \\
\hline HPZ003A & 201.58 & 202.18 & 0.60 & 200.38 & 201.12 & 0.74 & 201.18 & 201.73 & 0.55 & 0.26 & 0.22 & -0.04 \\
\hline HPZO04A & 210.47 & 218.76 & 8.29 & 209.90 & 197.67 & -12.23 & 210.12 & 206.99 & -3.13 & 0.07 & 3.52 & 3.45 \\
\hline HPZOOSA & 213.67 & 213.71 & 0.04 & 211.48 & 210.85 & -0.63 & 212.71 & 212.58 & -0.13 & 0.41 & 0.77 & 0.36 \\
\hline HPZ006A & 202.14 & 202.98 & 0.84 & 201.53 & 202.09 & 0.56 & 201.87 & 202.46 & 0.58 & 0.16 & 0.23 & 0.07 \\
\hline
\end{tabular}

Data for FPZ001A, FPZ002A, FPZ004A, FPZ005A, FPZ006A, HPZ002A, HPZ003A, HPZ004A, and HPZ005A based on continuous measurements. Data for FPZ003A, FPZ007A, FPZ008A, HPZ001A and HPZ006A based on monthly measurements.

${ }^{b}$ Pre-Operation period for F-Area piezometers was 1/96 - 3/97. Pre-Operation period for H-Area piezometers was 1/96 - 6/97.

- Positive numbers indicate the value since the Waste Treatment Unit began operation was greater than the pre-operation period value. Negative numbers indicate the value since the Waste Treatment Unit began operation was less than the pre-operation period value. 
Table 8. Comparison of the Piezometer Water-Level Statistics Before and After Waste Treatment Units Began Operating ${ }^{\mathrm{a}}$

\begin{tabular}{|c|c|c|c|c|c|c|c|c|c|c|c|c|}
\hline \multirow[b]{2}{*}{ Piezometer } & \multicolumn{3}{|c|}{ Maximum } & \multicolumn{3}{|c|}{ Minimum } & \multicolumn{3}{|c|}{ Average } & \multicolumn{3}{|c|}{ Standard Deviation } \\
\hline & $\begin{array}{l}\text { Pre-Op, } \\
\text { Period }^{b}\end{array}$ & $\begin{array}{l}\text { Post-Op. } \\
\text { Period }^{c}\end{array}$ & Difference $^{d}$ & $\begin{array}{l}\text { Pre-Op. } \\
\text { Period }^{b}\end{array}$ & $\begin{array}{l}\text { Post-Op. } \\
\text { Period }^{\mathrm{c}}\end{array}$ & Difference $^{d}$ & $\begin{array}{l}\text { Pre-Op. } \\
\text { Period }^{b}\end{array}$ & $\begin{array}{l}\text { Post-Op. } \\
\text { Period }^{c}\end{array}$ & Difference $^{d}$ & $\begin{array}{l}\text { Pre-Op. } \\
\text { Period }^{b}\end{array}$ & $\begin{array}{l}\text { Post-Op. } \\
\text { Period }^{c}\end{array}$ & Difference ${ }^{d}$ \\
\hline FPZO01A & 198.10 & 198.21 & 0.11 & 197.80 & 197.79 & -0.01 & 197.91 & 197.99 & 0.08 & 0.08 & 0.07 & 0.01 \\
\hline FPZO02A & 201.91 & 203.36 & 1.45 & 200.97 & 200.38 & -0.59 & 201.21 & 201.70 & 0.49 & 0.22 & 0.73 & 0.51 \\
\hline FPZO03A & 191.22 & 191.97 & 0.75 & 187.07 & 186.12 & -0.95 & 188.87 & 188.70 & .0 .17 & 1.18 & 1.76 & 0.58 \\
\hline FPZ004A & 202.46 & 202.89 & 0.43 & 200.90 & 200.35 & -0.55 & 201.21 & 201.48 & 0.27 & 0.15 & 0.65 & 0.50 \\
\hline FPZO05A & 191.30 & 191.57 & 0.27 & 190.99 & 189.45 & -1.54 & 191.09 & 190.95 & -0.14 & 0.05 & 0.44 & 0.39 \\
\hline FPZ006A & 189.81 & 191.94 & 2.13 & 188.50 & 187.94 & -0.565 & 189.15 & 189.36 & 0.21 & 0.26 & 0.53 & 0.26 \\
\hline FPZ007A & 193.34 & 193.46 & 0.12 & 192.66 & 186.12 & -6.54 & 193.02 & 193.03 & 0.01 & 0.17 & 0.27 & 0.10 \\
\hline FPZ008A & 187.72 & 187.79 & 0.07 & 187.56 & 192.48 & 4.92 & 187.63 & 187.65 & 0.02 & 0.05 & 0.07 & 0.02 \\
\hline HPZ001A & 202.38 & 202.68 & 0.30 & 202.05 & 201.87 & -0.18 & 202.31 & 202.23 & -0.07 & 0.08 & 0.16 & 0.08 \\
\hline HPZOO2A & 218.78 & 219.74 & 0.96 & 217.44 & 216.39 & -1.05 & 218.03 & 218.12 & 0.09 & 0.27 & 0.80 & 0.53 \\
\hline HPZ003A & 201.58 & 202.18 & 0.60 & 200.38 & 201.07 & 0.69 & 201.18 & 201.64 & 0.46 & 0.26 & 0.25 & -0.01 \\
\hline $\mathrm{HPZOOAA}$ & 210.47 & 218.76 & 8.29 & 209.90 & 197.67 & -12.23 & 210.12 & 207.98 & -2.14 & 0.07 & 3.31 & 3.24 \\
\hline HPZ005A & 213.67 & 213.71 & 0.04 & 211.48 & 210.78 & -0.70 & 212.71 & 212.54 & -0.16 & 0.41 & 0.78 & 0.37 \\
\hline HPZ006A & 202.14 & 202.98 & 0.84 & 201.53 & 201.93 & 0.40 & 201.87 & 202.36 & 0.48 & 0.16 & 0.24 & 0.07 \\
\hline
\end{tabular}

${ }^{2}$ Data for FPZ001A, FPZ002A, FPZ004A, FPZ005A, FPZ006A, HPZ002A, HPZ003A, HPZ004A, and HPZ005A based on continuous measurements. Data for FPZ003A, FPZ007A, FPZ008A, HPZ001A and HPZ006A based on monthly measurements.

${ }^{b}$ Pre-Operation period for F-Area piezometcrs was 1/96-3/97. Pre-Operation period for H-Area piezometers was 1/96 - 6/97.

c Post-Operation period for F-Area piezometers was 4/97 - 12/98. Post-Operation period for H-Area piezometers was 7/97 - $12 / 98$.

' Positive numbers indicate the value since the Waste Treatment Unit began operation was greater than the pre-operation period value. Negative numbers indicate the value since the Waste Treatment Unit began operation was less than the pre-operation period value. 


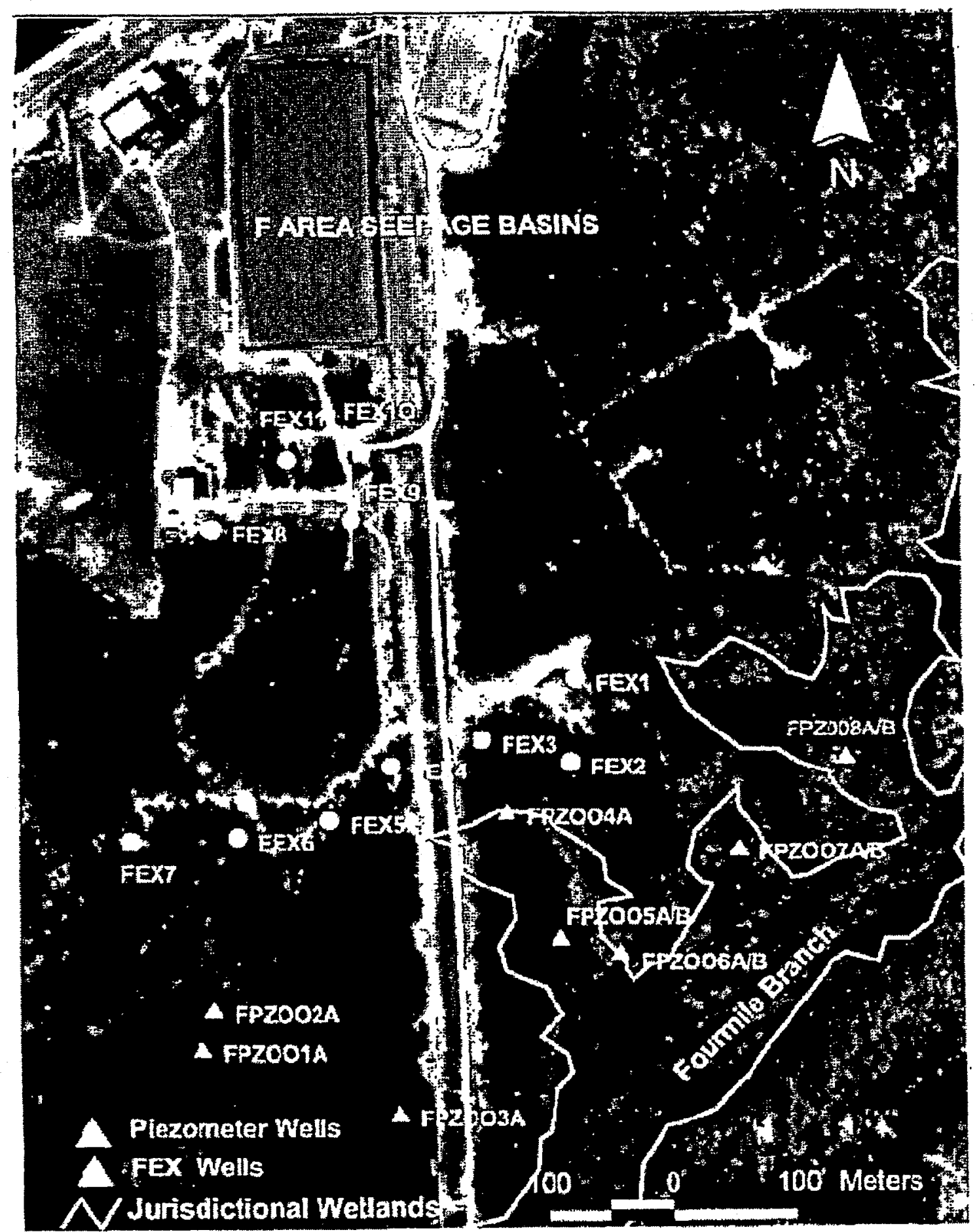

Figure 1. Extraction/injection well locations and piezometer locations for the water table aquifer in F-Area 


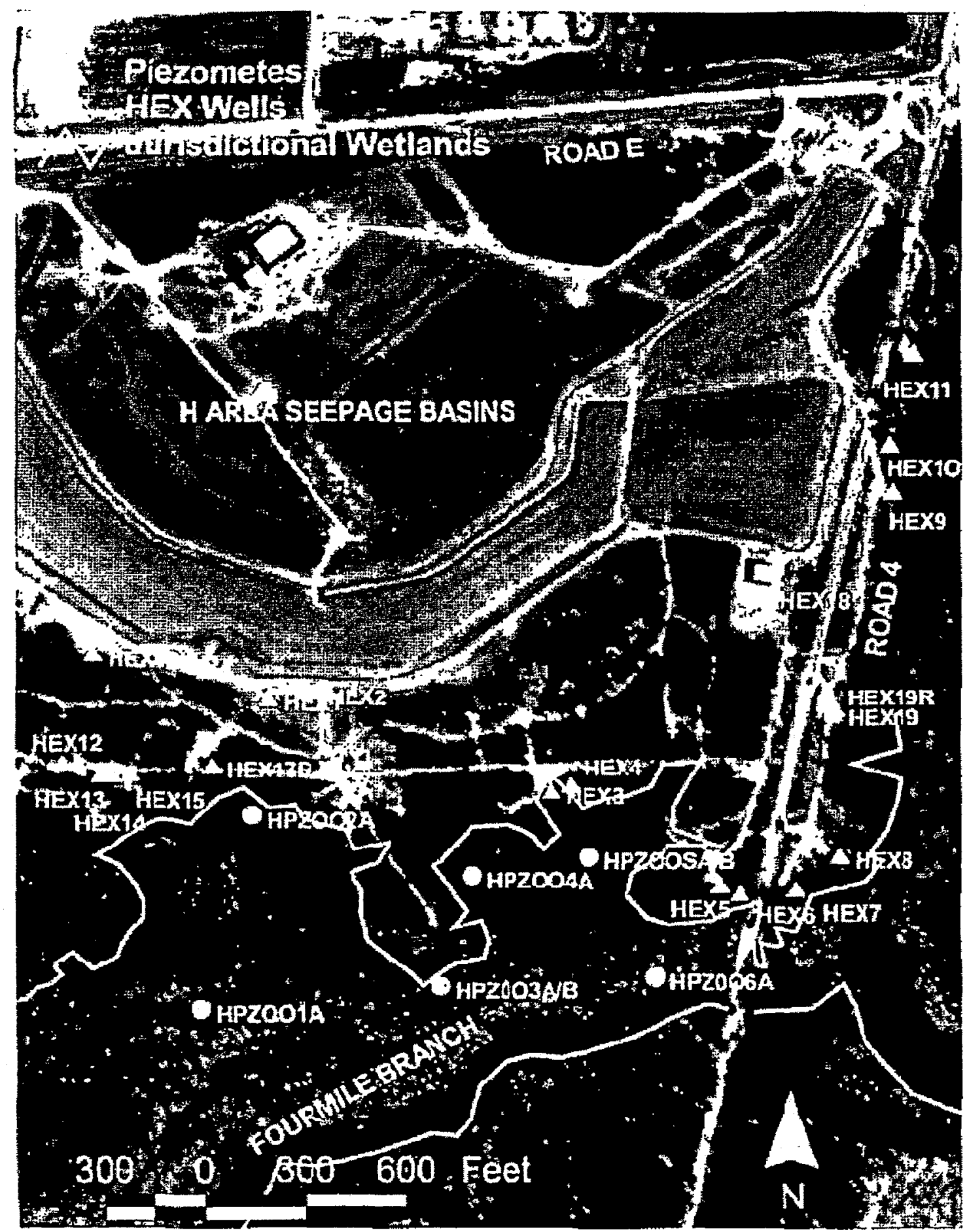

Figure 2. Extraction/injection well locations and piezometer locations for the water table aquifer in H-Area 


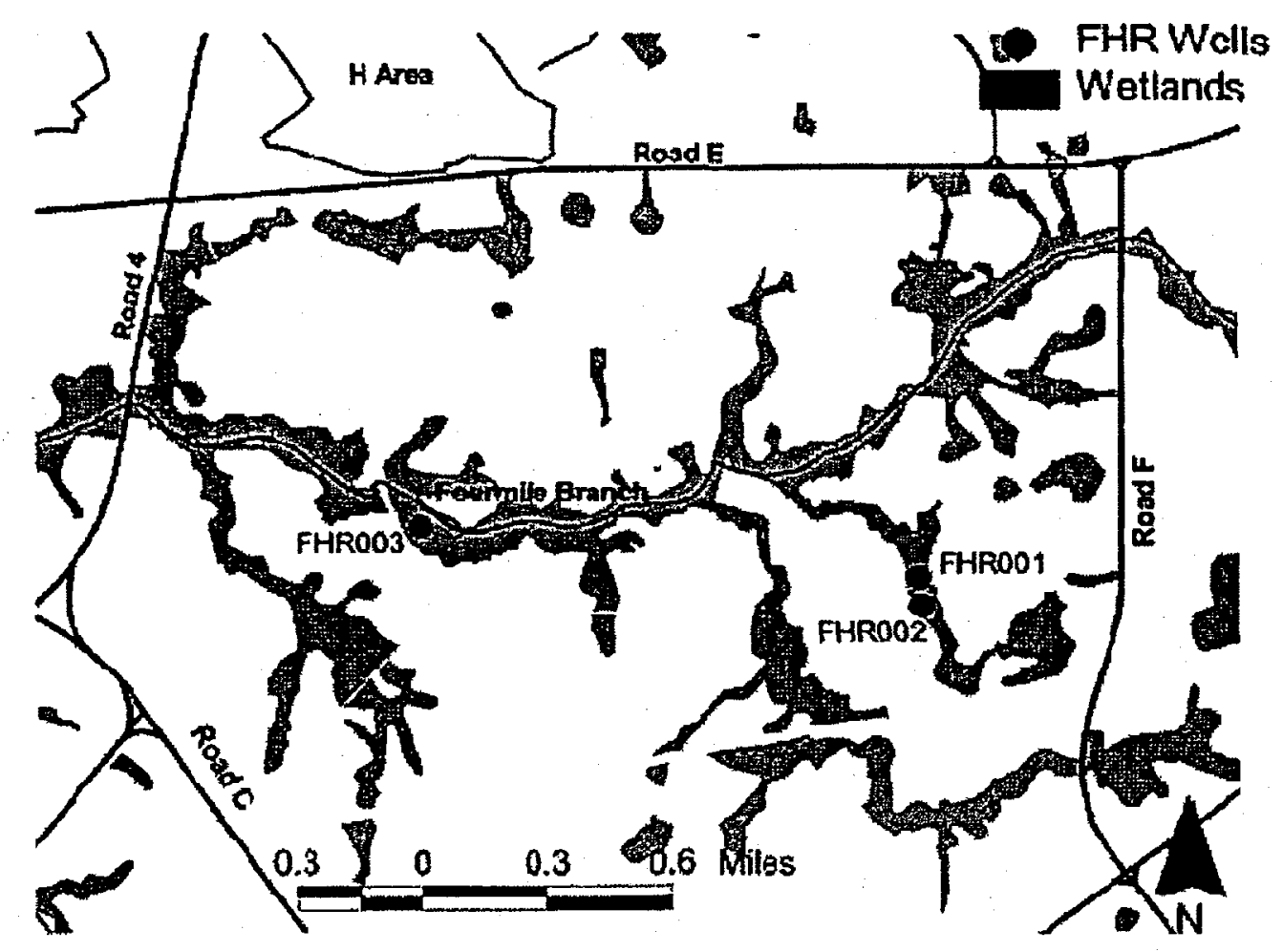

Figure 3. Reference piezometer locations 


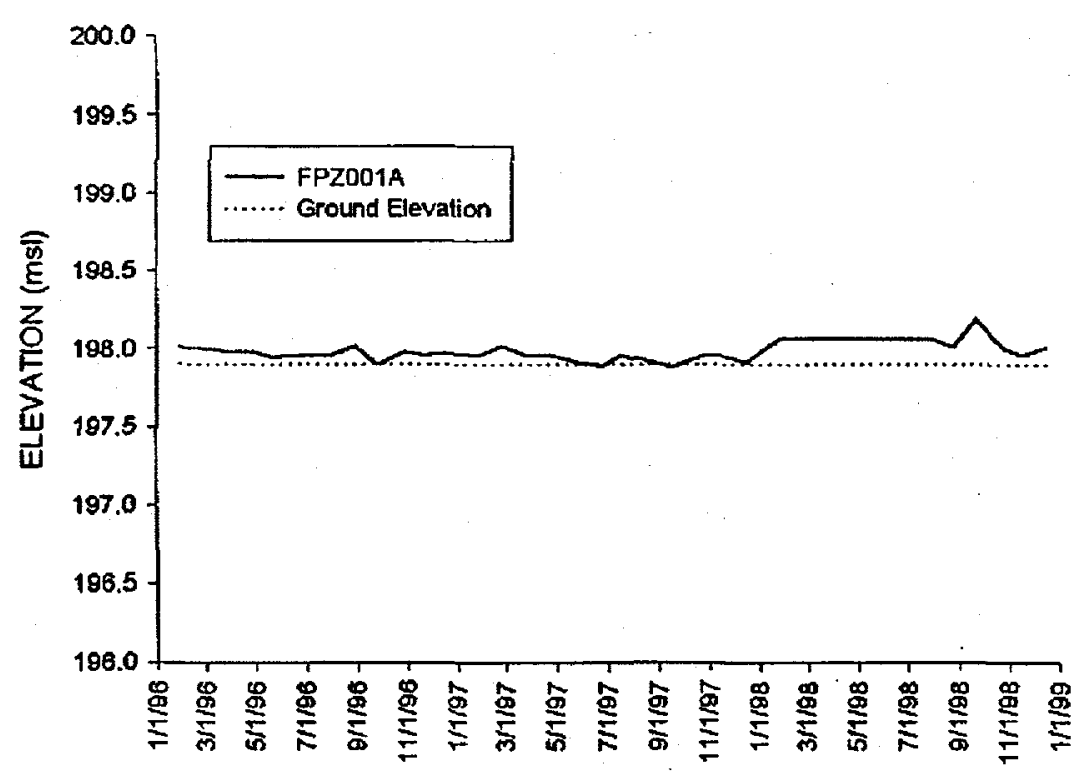

Figure 4. Water level elevations at location FPZ001A, January 1996 to December 1998

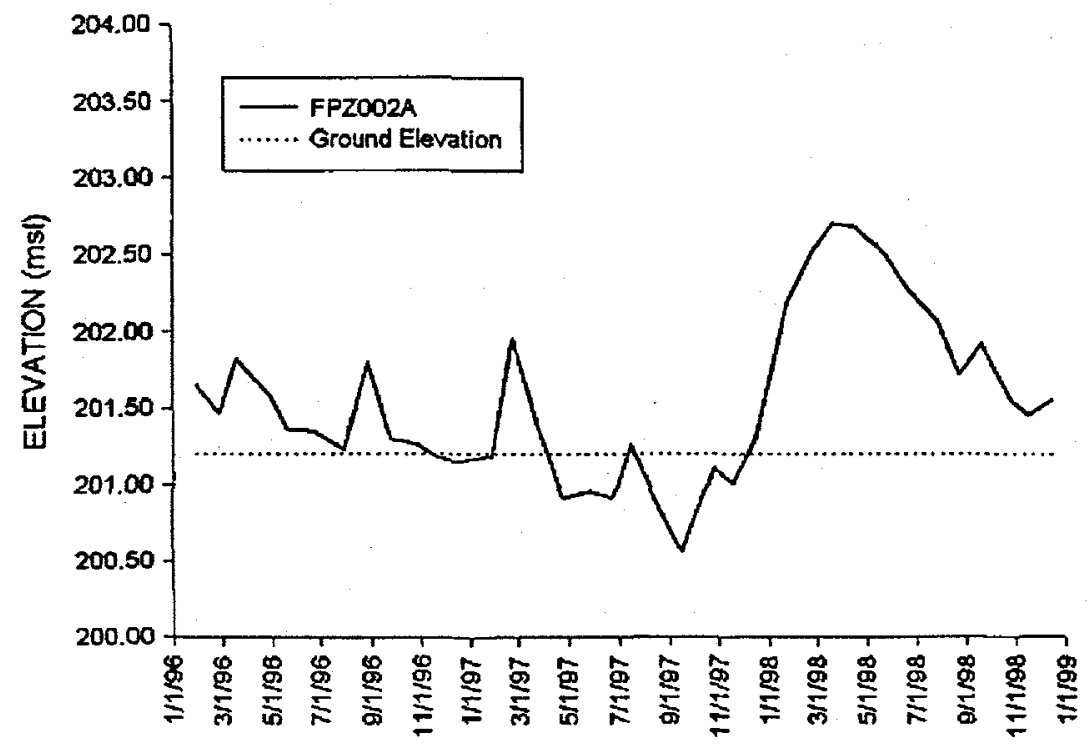

Figure 5. Water level elevations at location FPZ002A, January 1996 to December 1998 


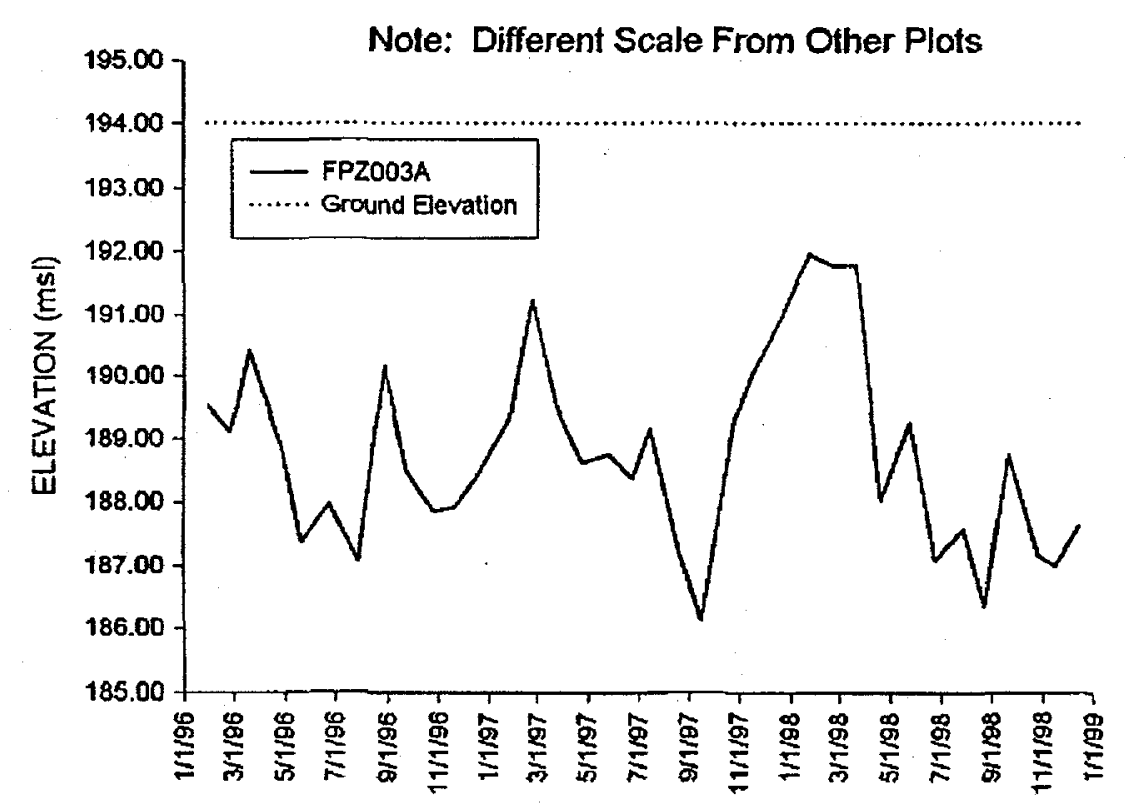

Figure 6. Water level elevations at location FPZ003A, January 1996 to December 1998

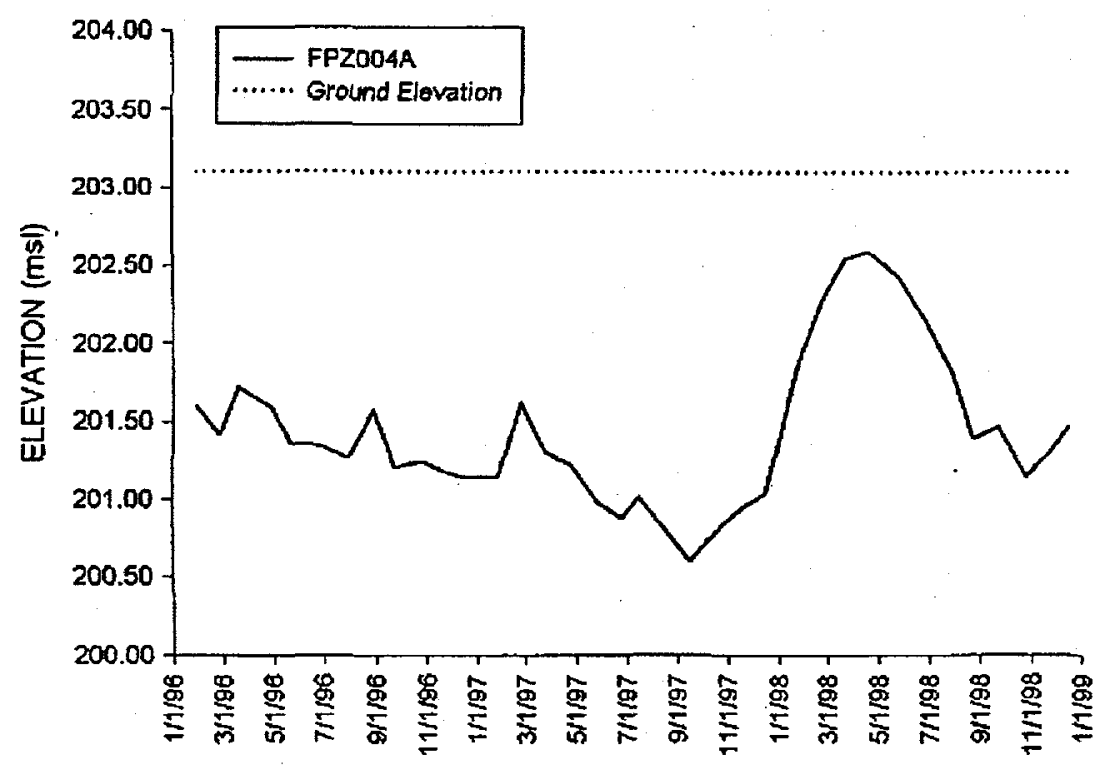

Figure 7. Water level elevations at location FPZ004A, January 1996 to December 1998 

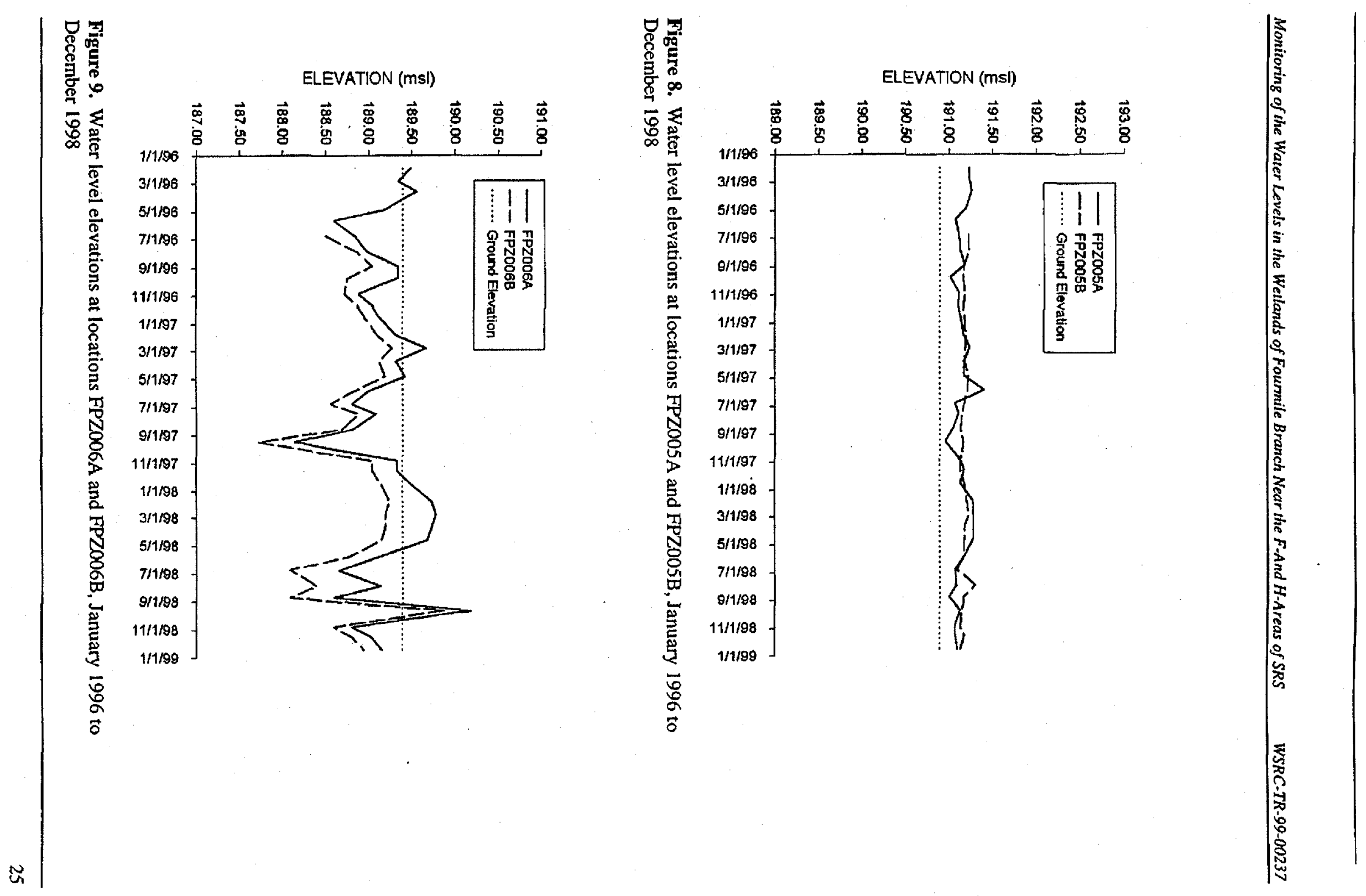


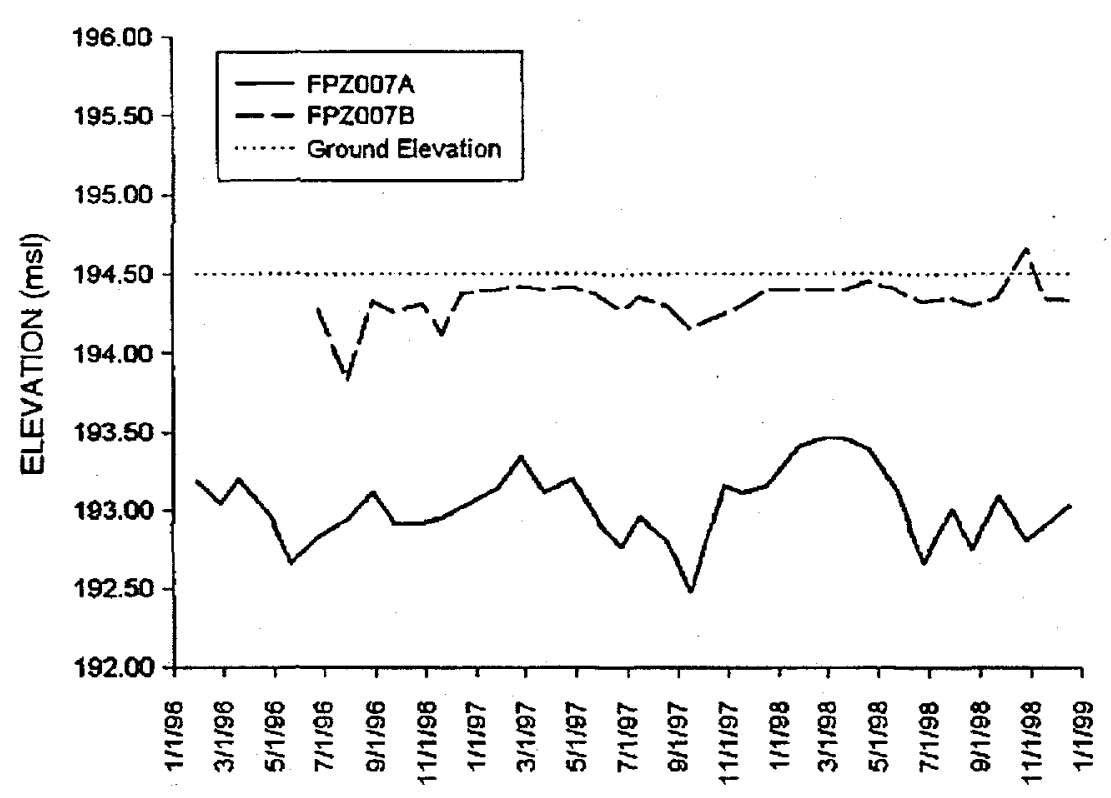

Figure 10. Water level elevations at locations FPZ007A and FPZ007B, January 1996 to December 1998

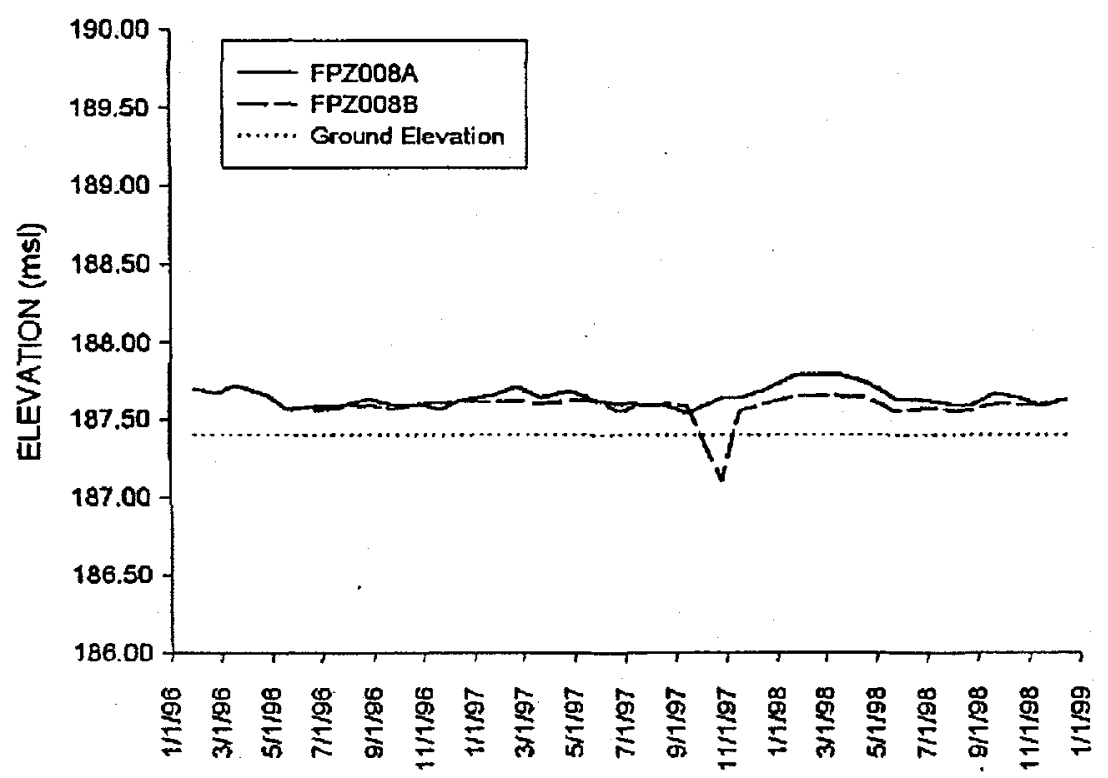

Figure 11. Water level elevations at locations FPZO08A and FPZO08B, January 1996 to December 1998 


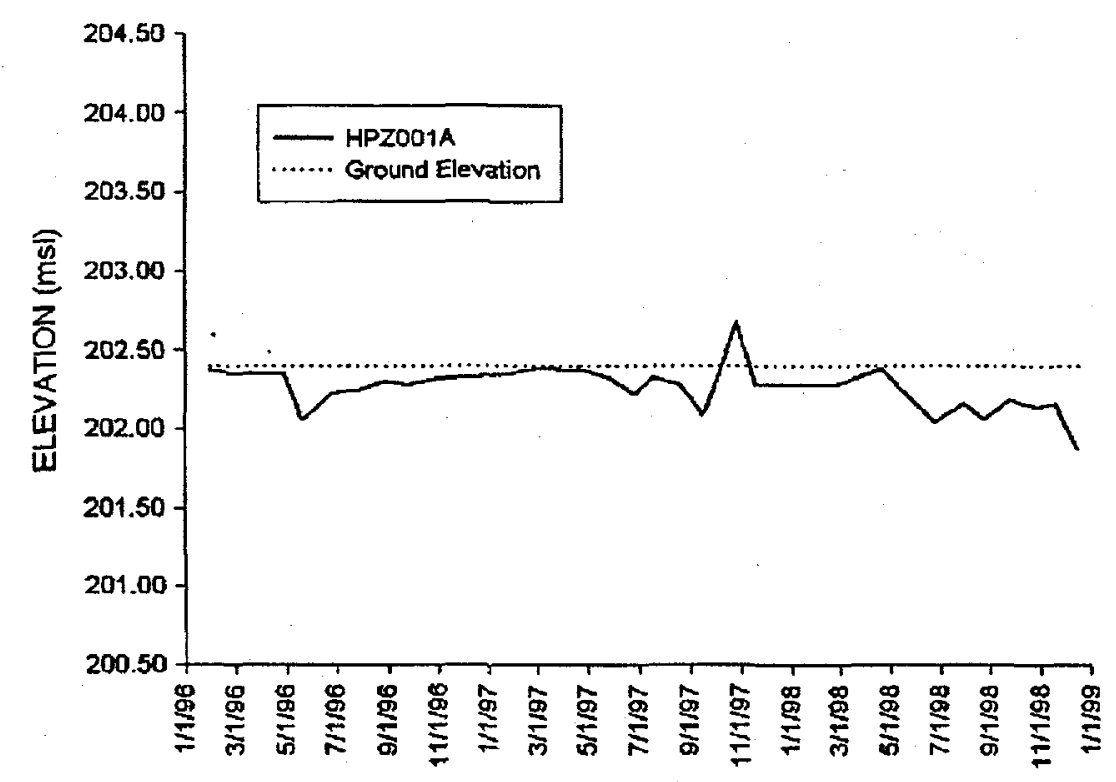

Figure 12. Water level elevations at location HPZ001A, January 1996 to December 1998

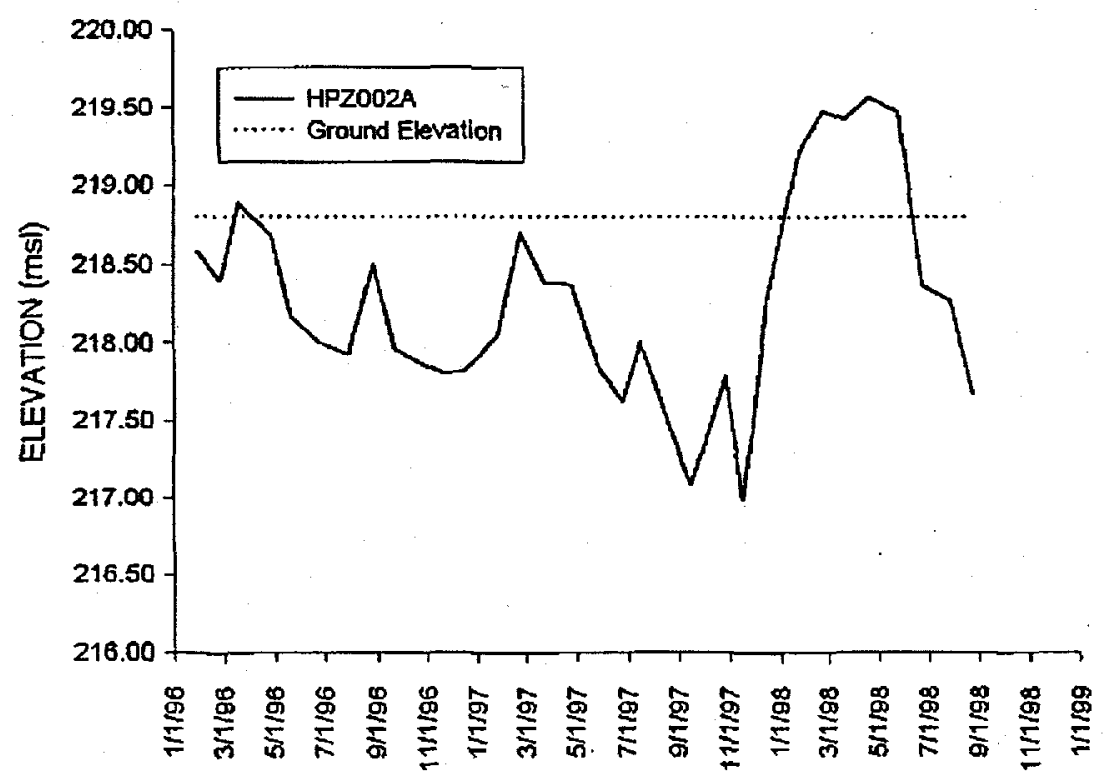

Figure 13. Water level elevations at location HPZ002A, January 1996 to December 1998 


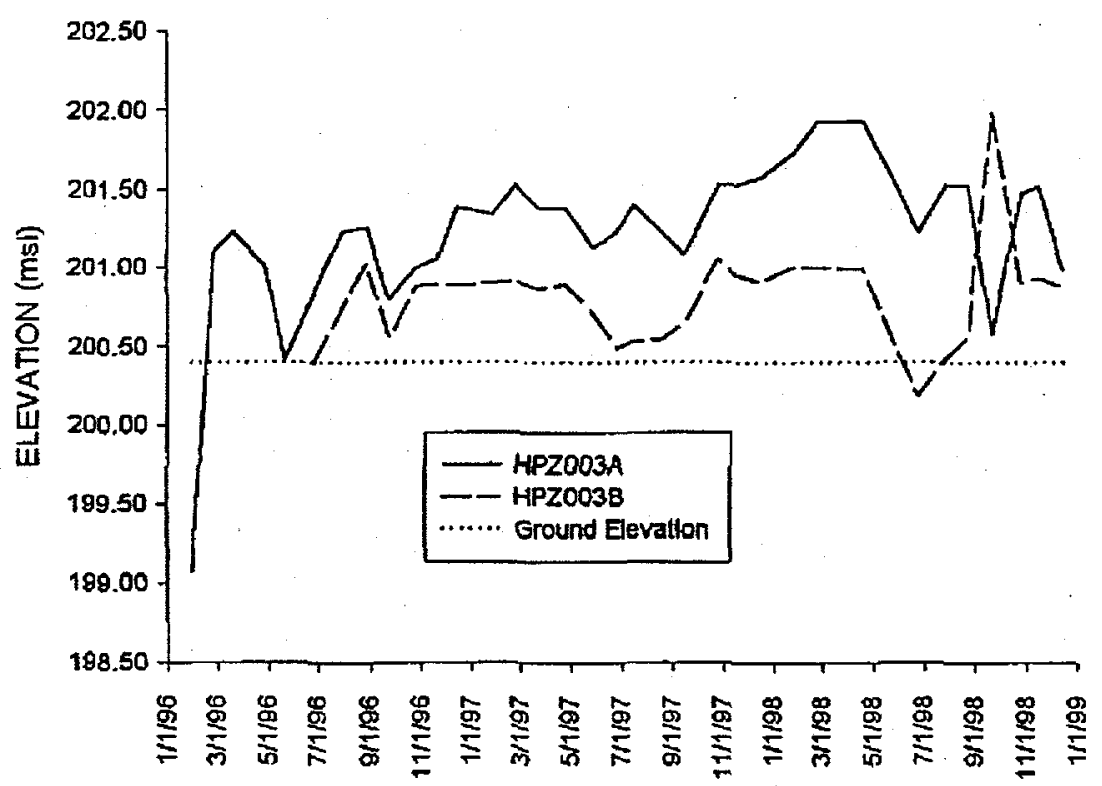

Figure 14. Water level elevations at locations HPZ003A and HPZ003B, January 1996 to December 1998

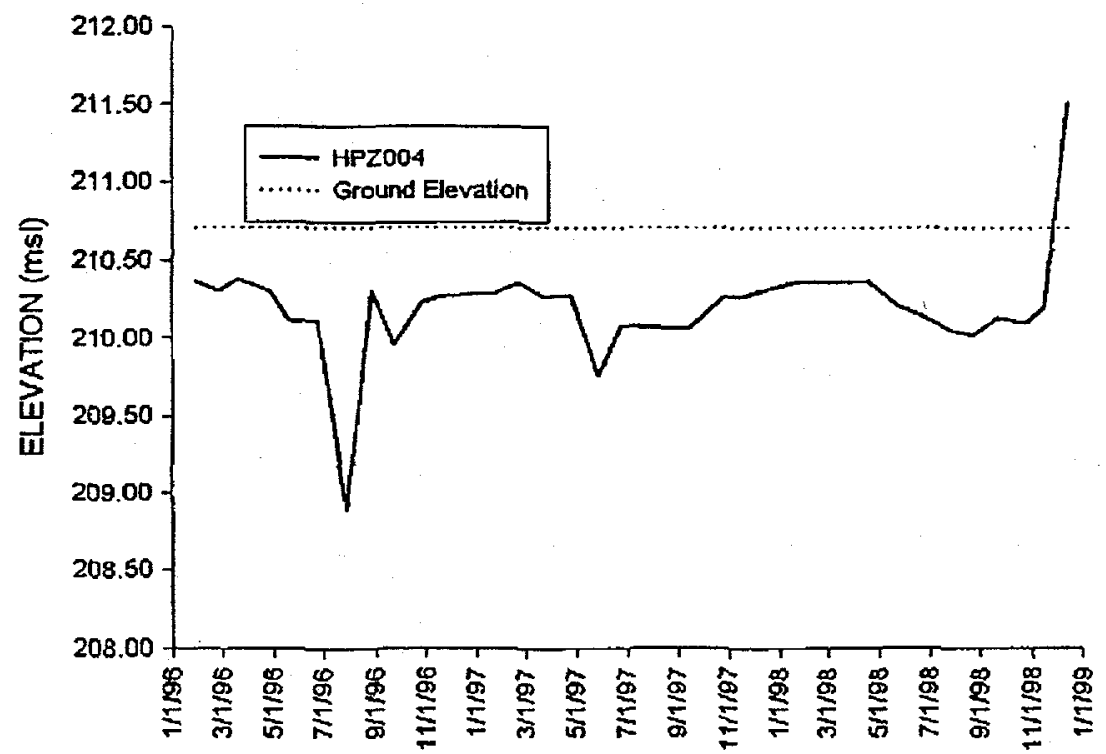

Figure 15. Water level elevations at location HPZ004A, January 1996 to December 1998 


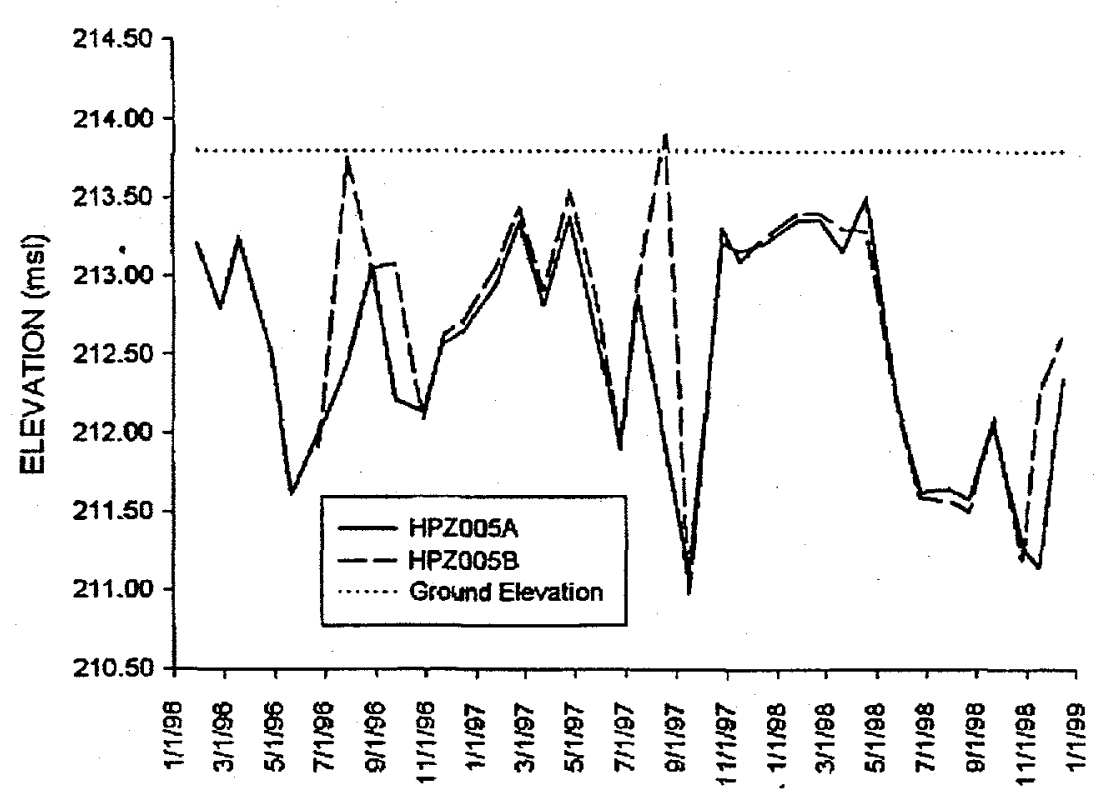

Figure 16. Water level elevations at locations HPZ005A and HPZO05B, January 1996 to December 1998

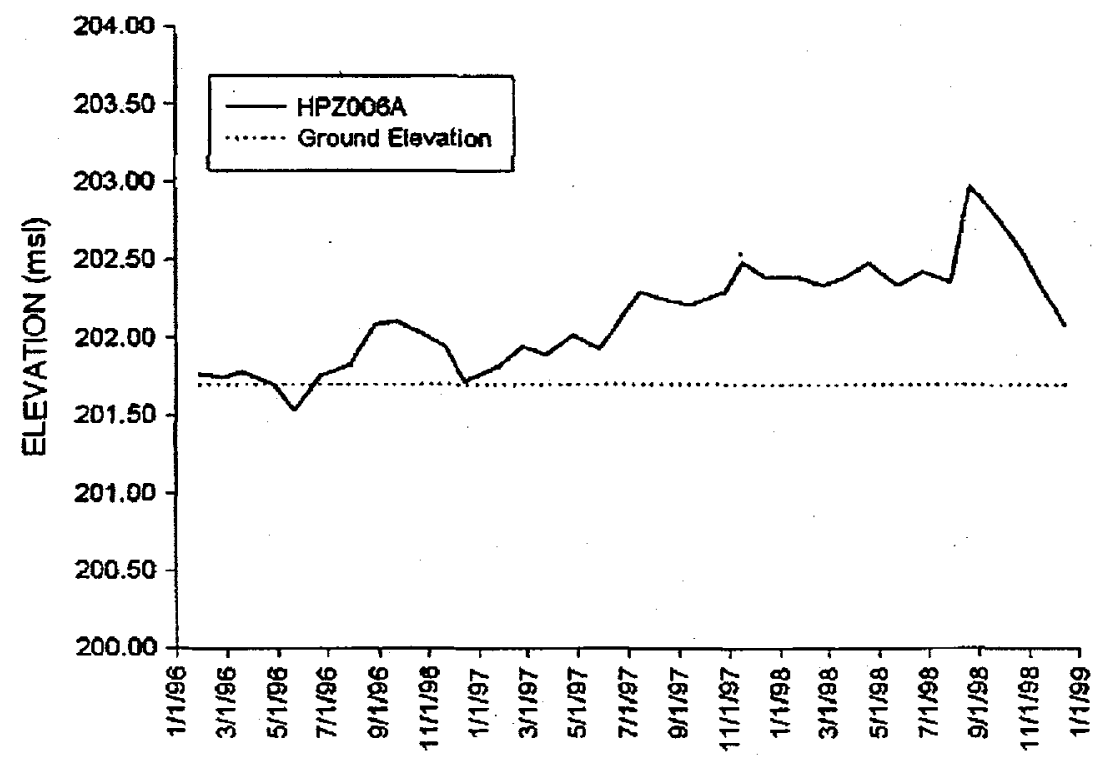

Figure 17. Water level elevations at location HPZ006A, January 1996 to December 1998 


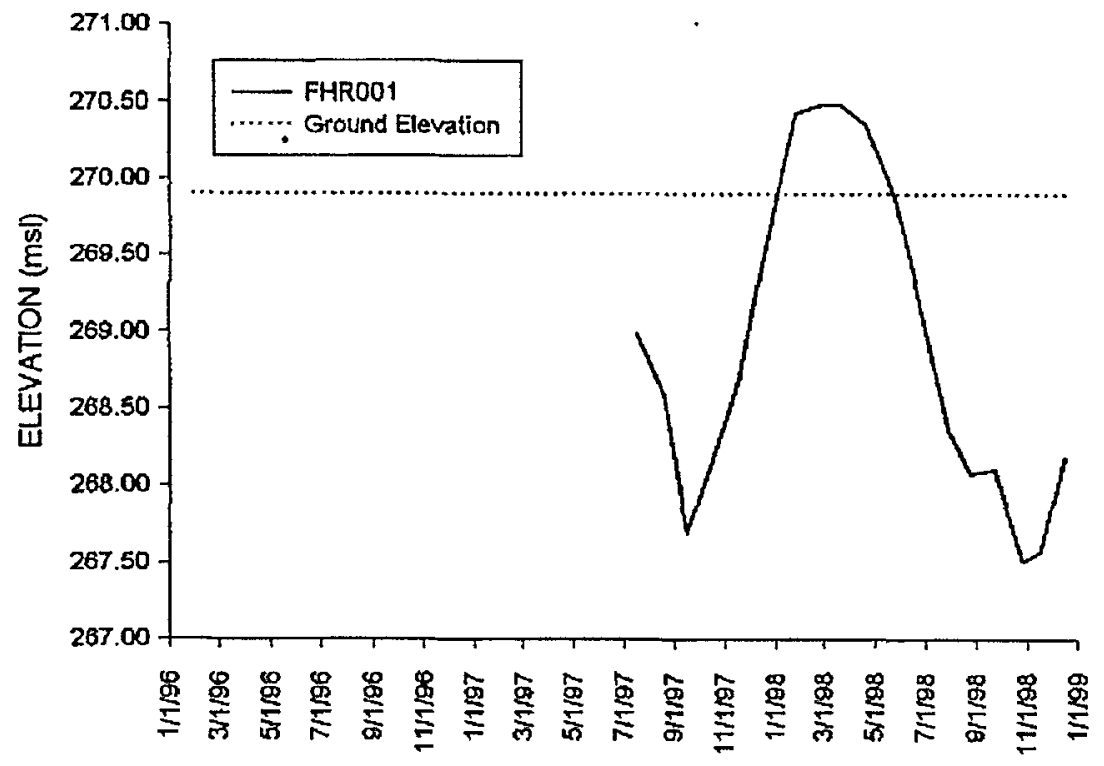

Figure 18. Water level elevations at location FHR001, July 1997 to December 1998

Note: Different Scale From Other Plots

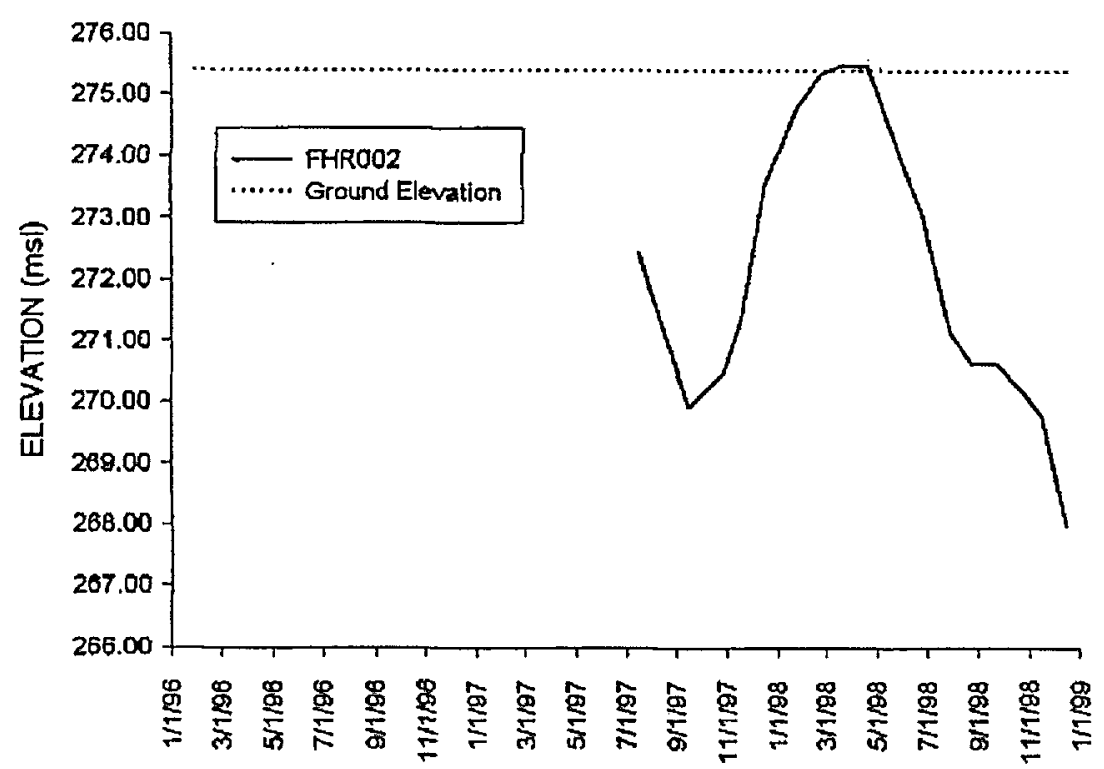

Figure 19. Water level elevations at location FHR002, July 1997 to December 1998 


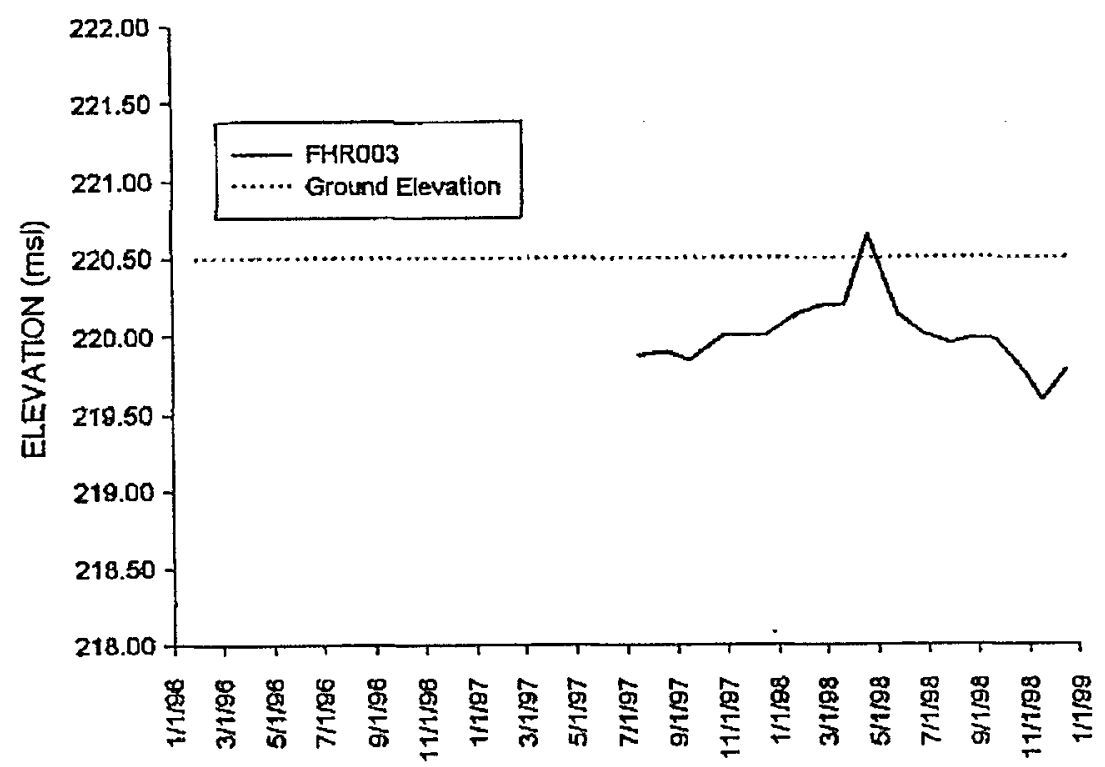

Figure 20. Water level elevations at location FHR003, July 1997 to December 1998 


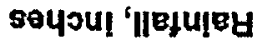

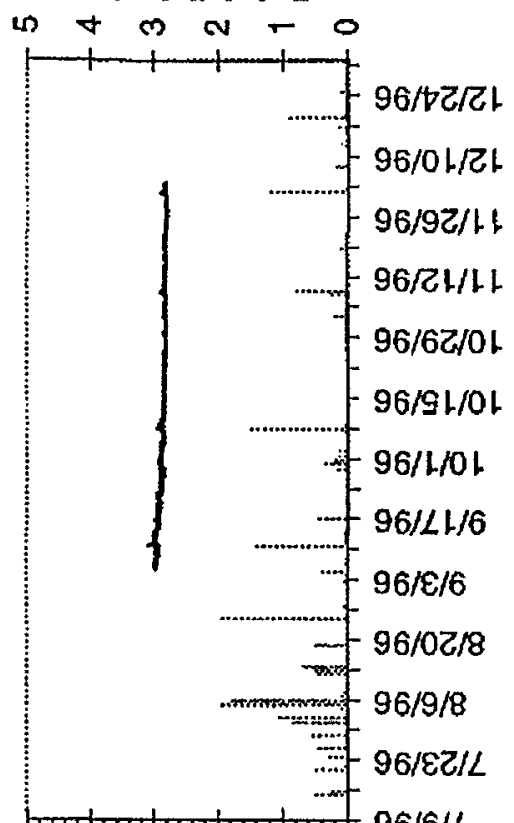

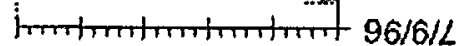

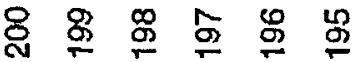

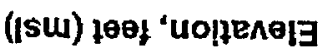

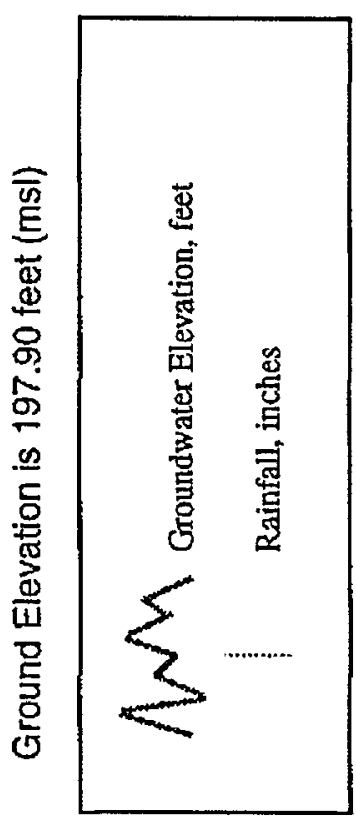

seyou! 'flejuley

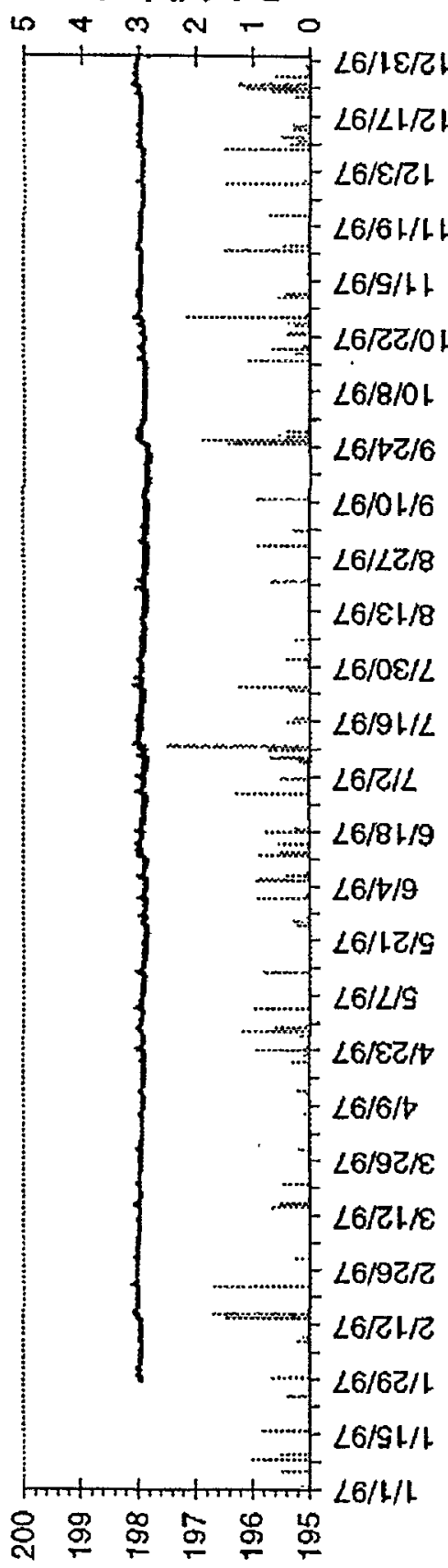

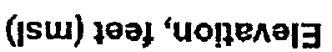

seyou! '"lleju!ey

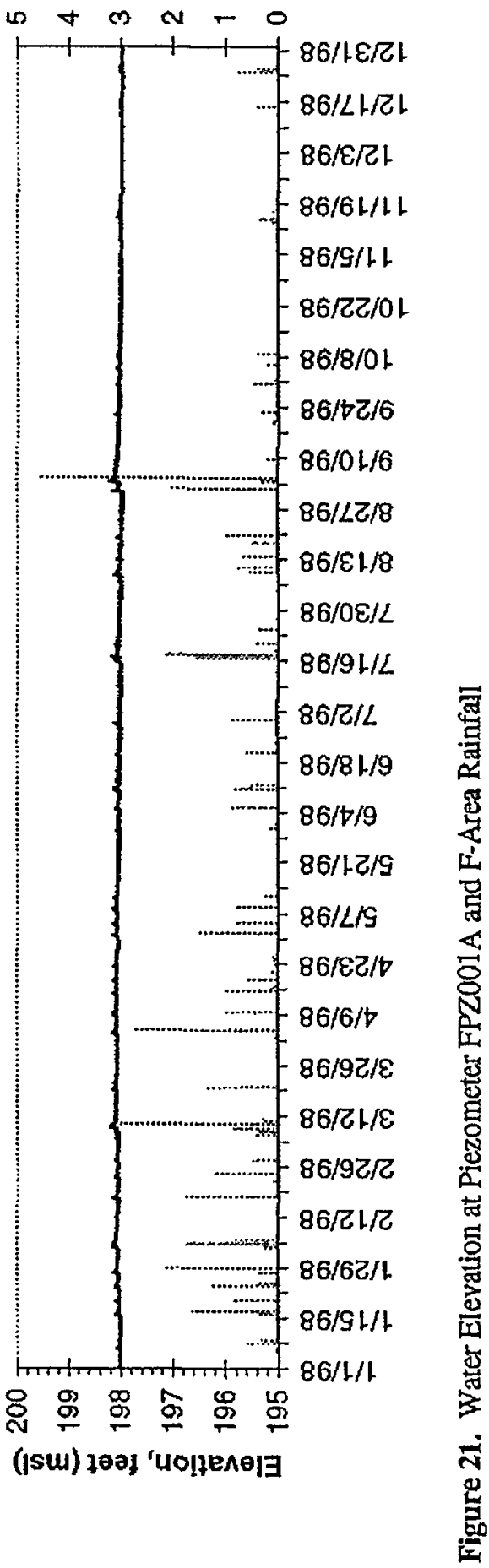



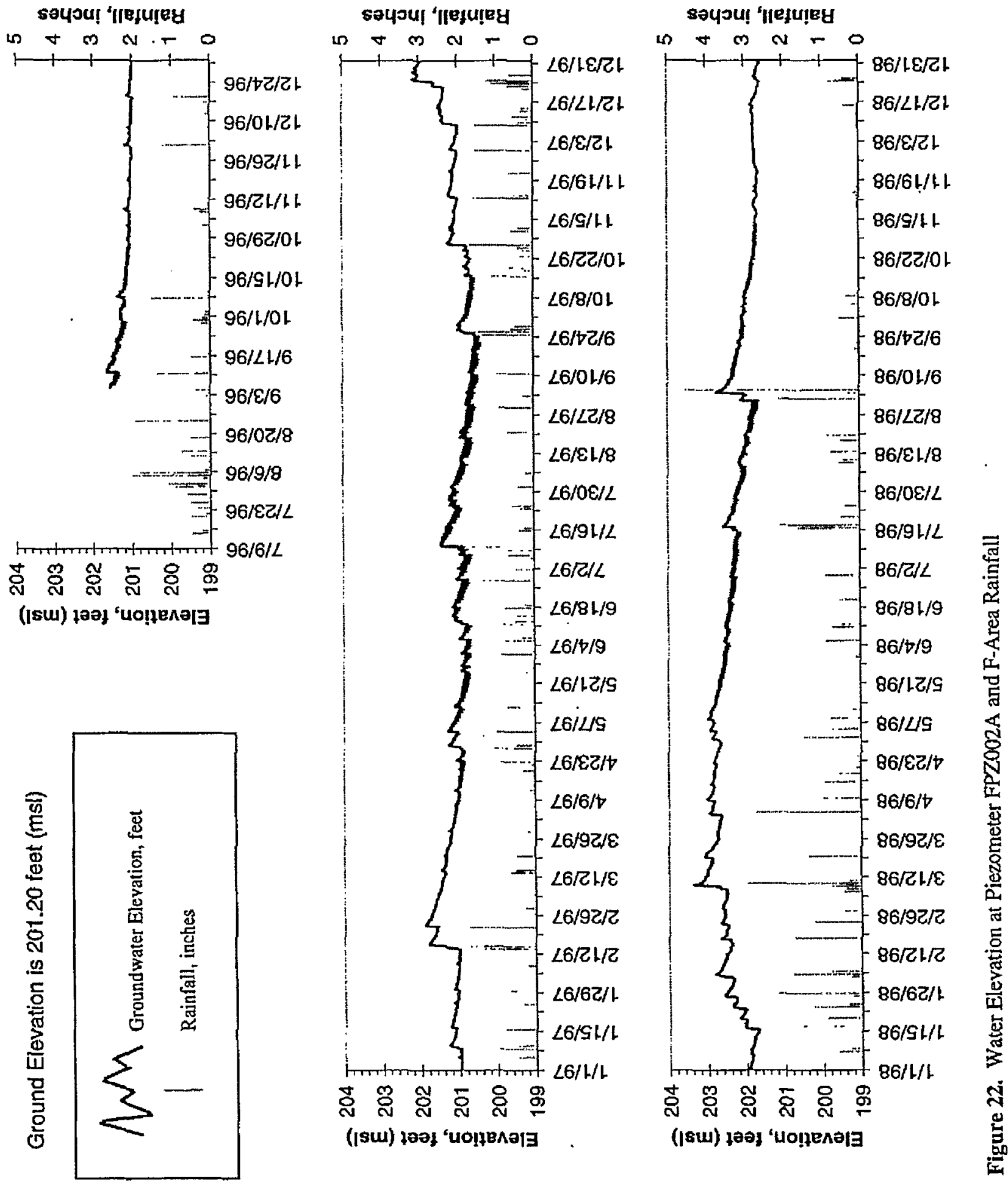
sayou! 'Ifefuiger

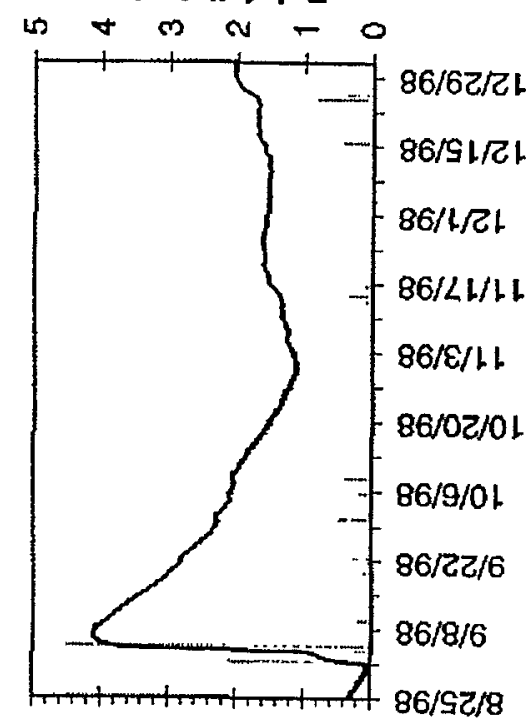

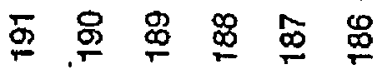

loaj 'uolfen⿻コ一

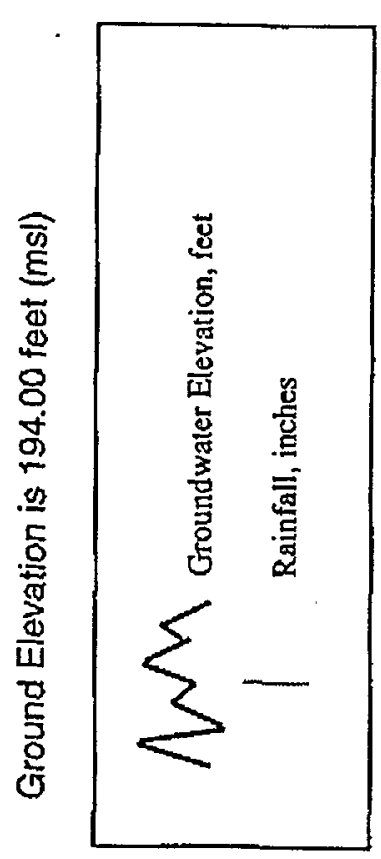

言 

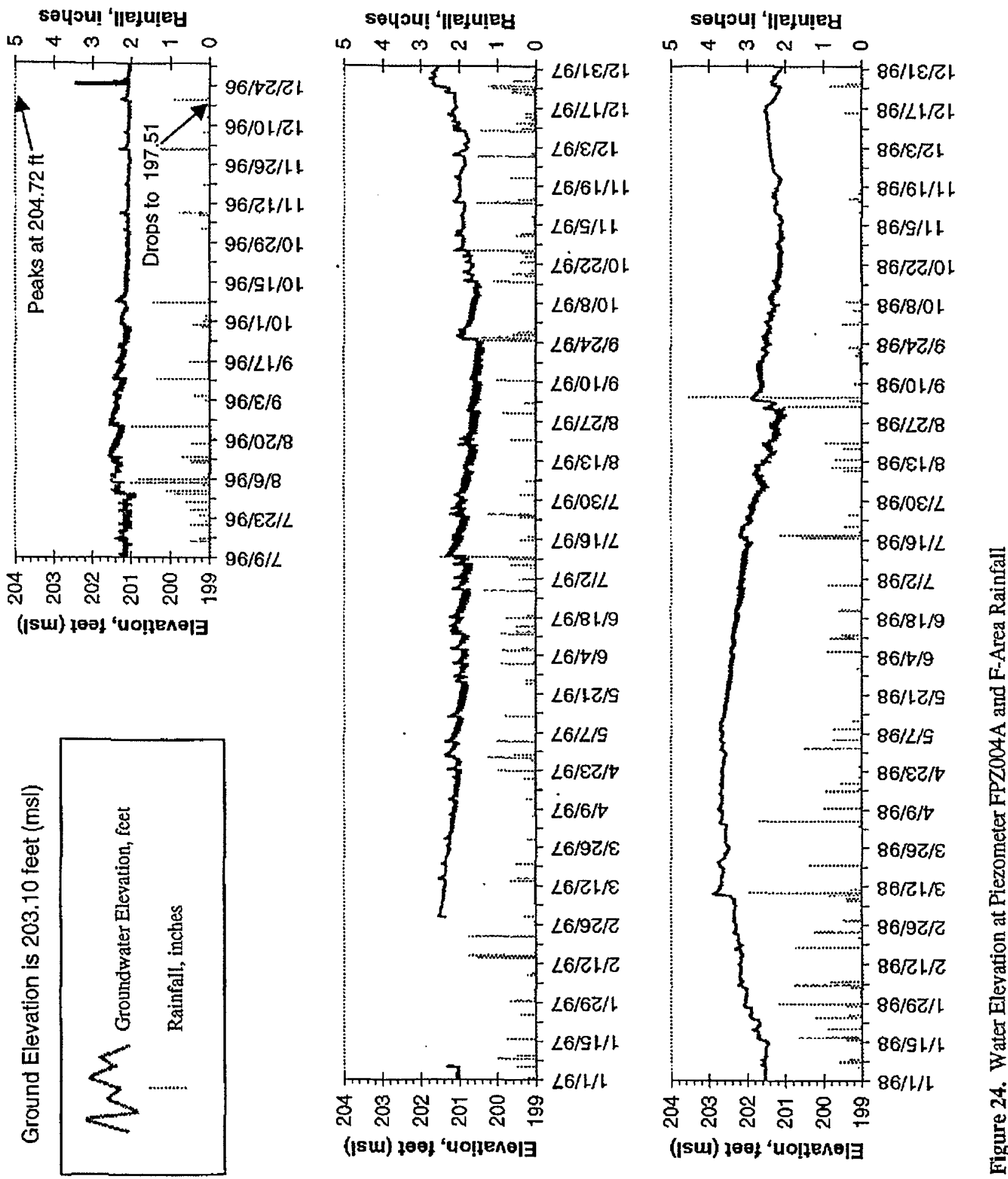


\section{$M_{\text {Groundwater Elevation, feet }}$ \\ Rainfall, inches}
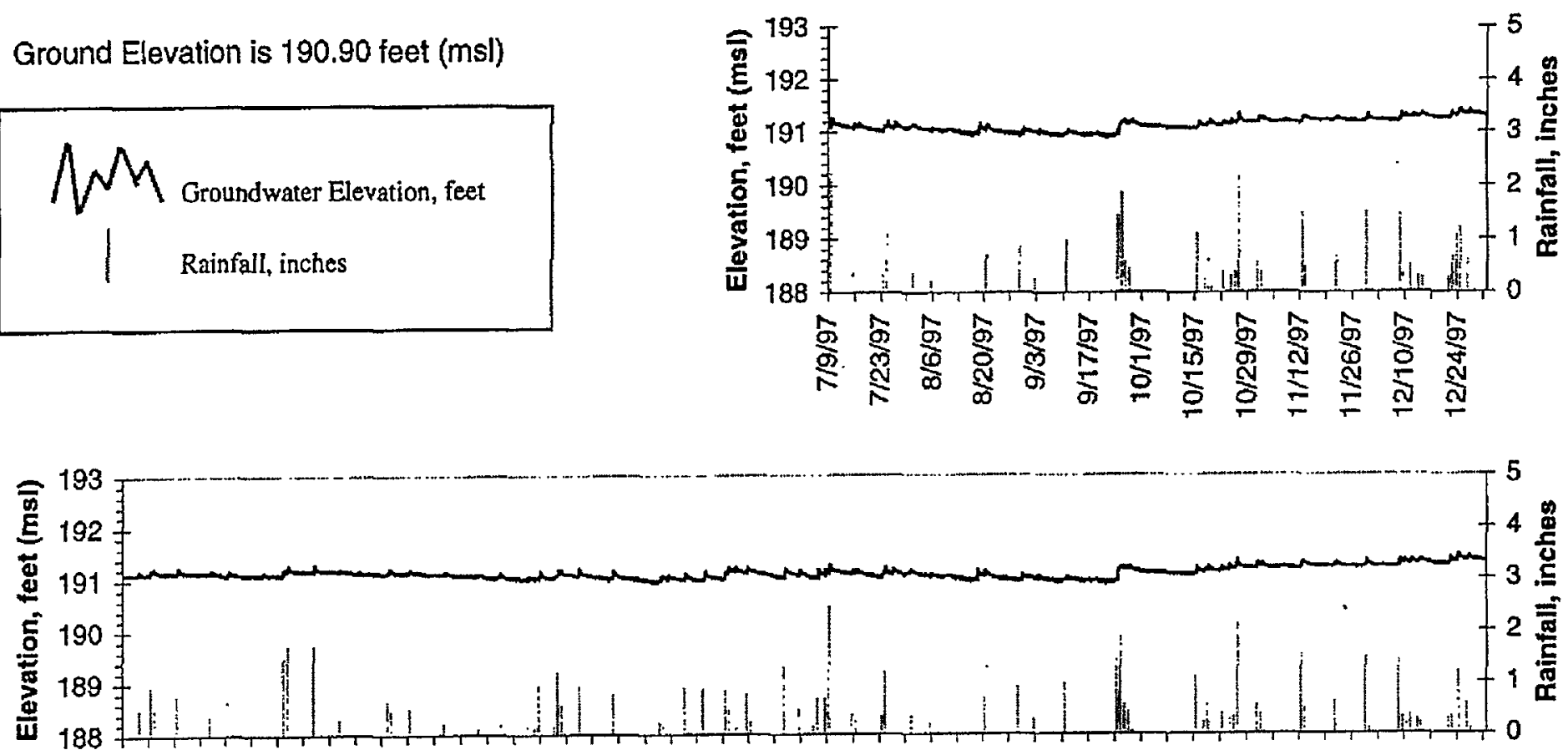

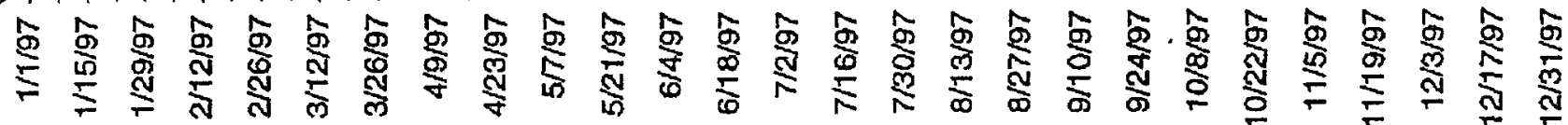

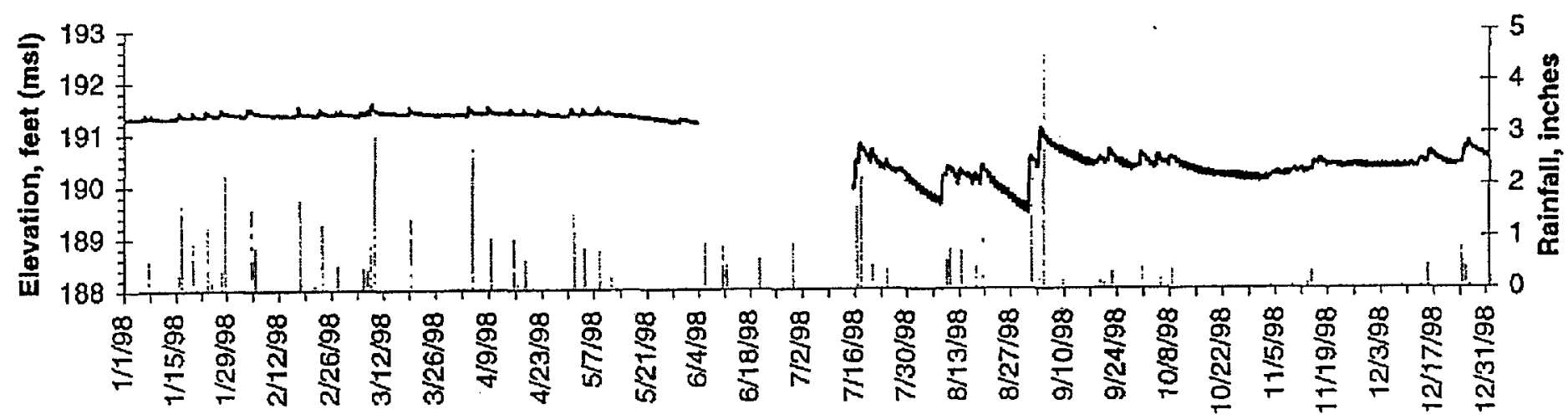

Figure 25. Water Elevation at Piezometer FPZ005A and F-Area Rainfall 

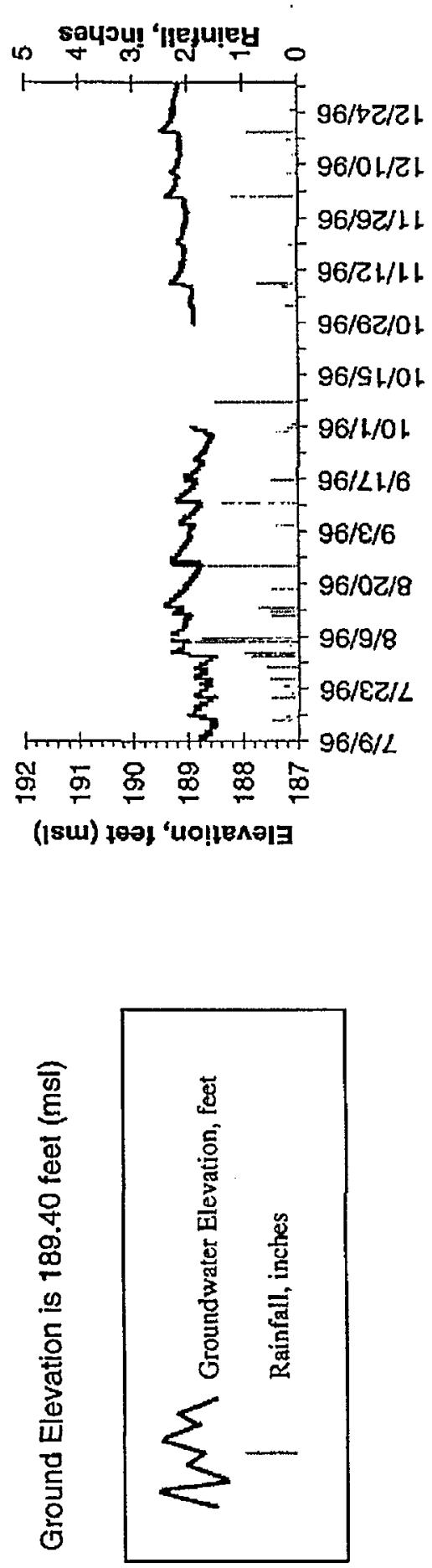

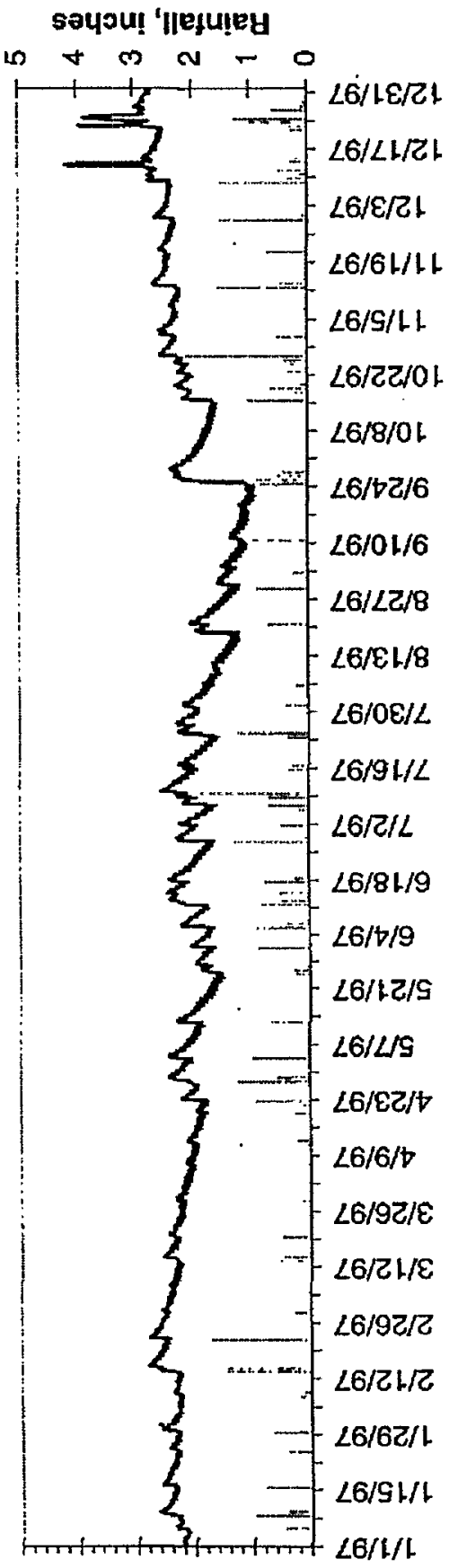

๙ (Isw) әㅣ 'иоำекә|э

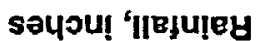

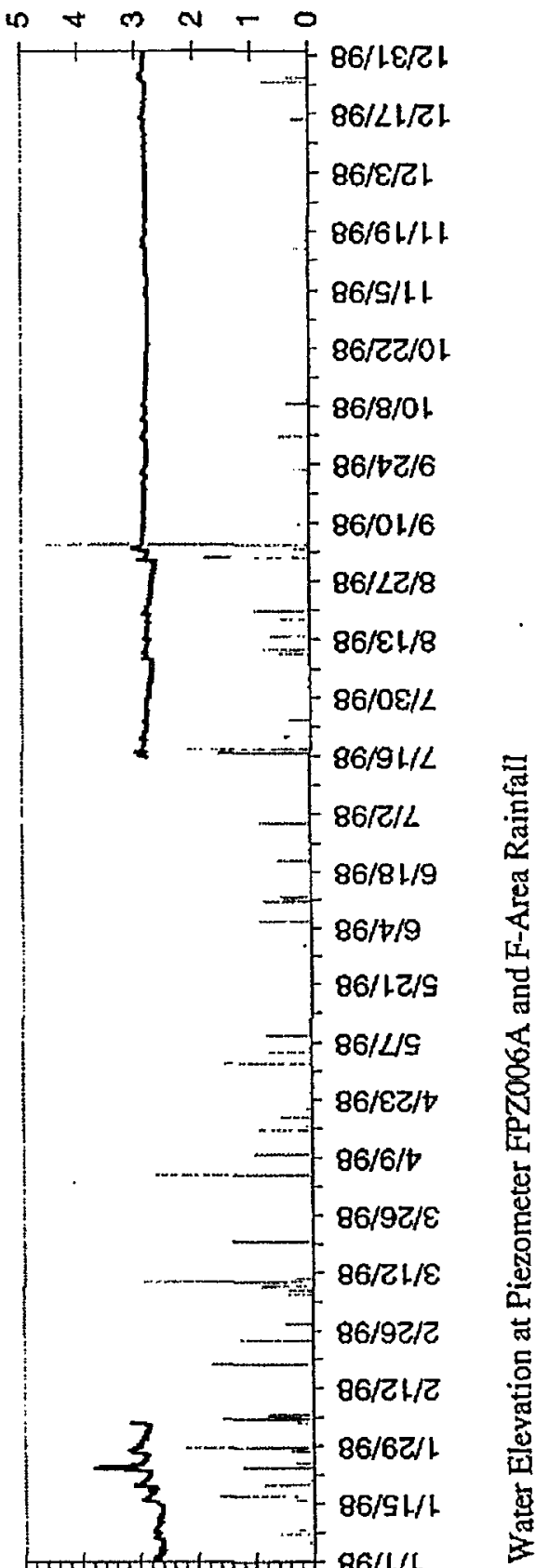

๙ั

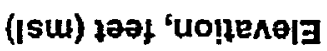




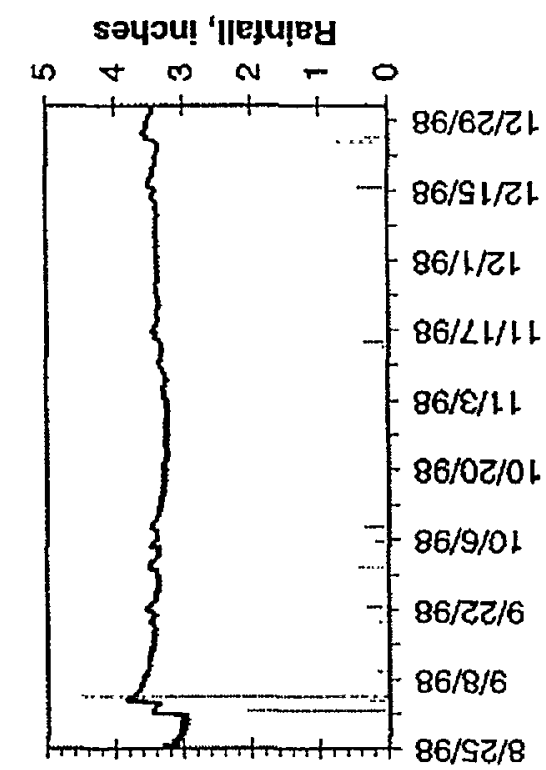

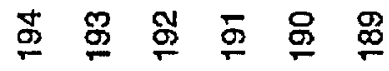

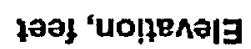

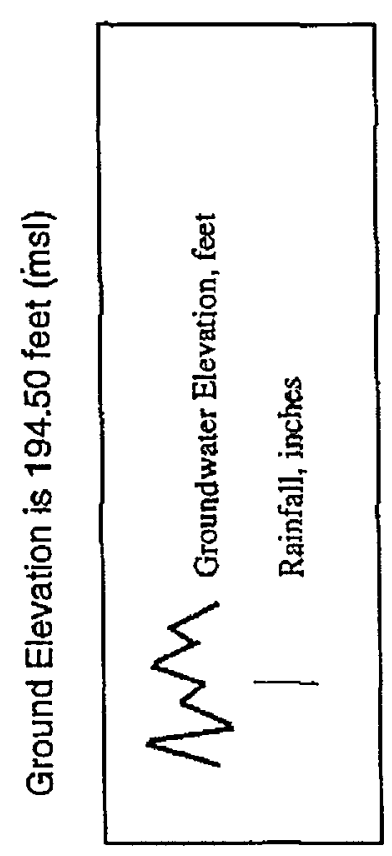

sayoul ‘feju!̣ey

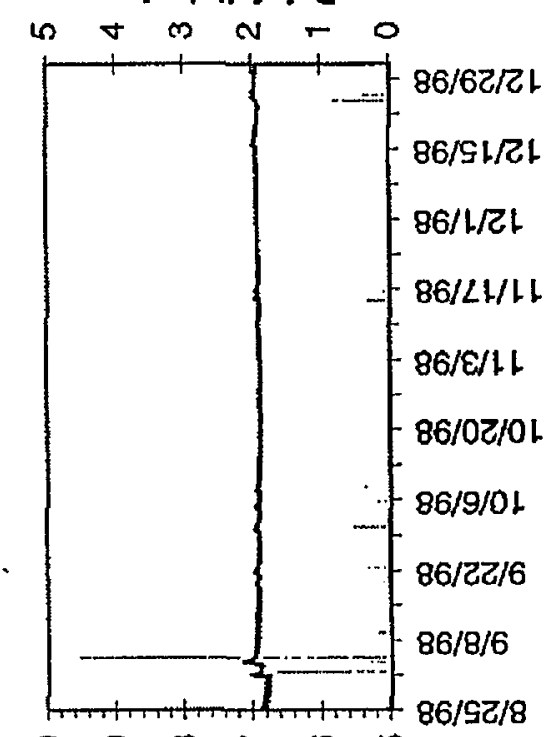

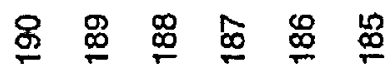

각 'uoplena|a

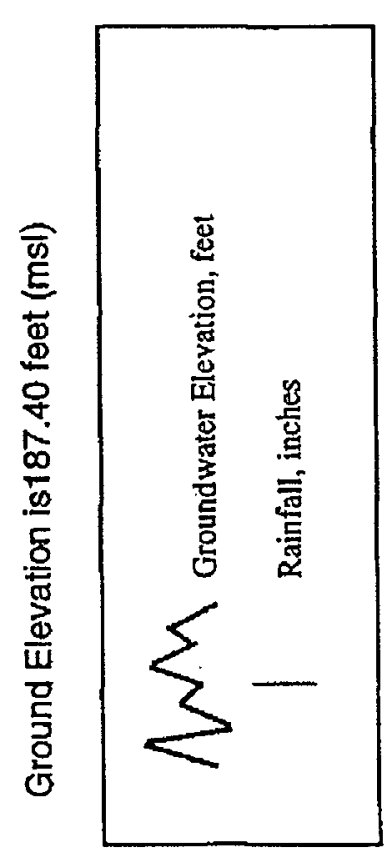




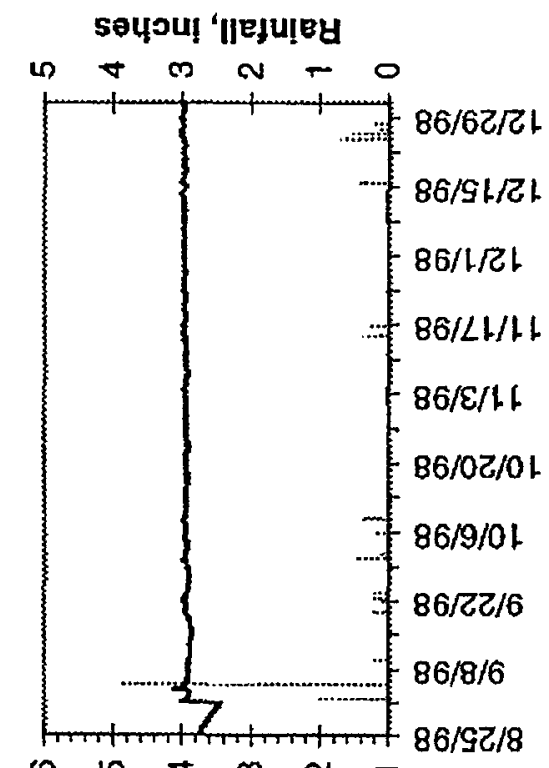

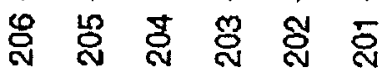

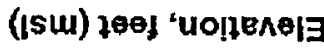

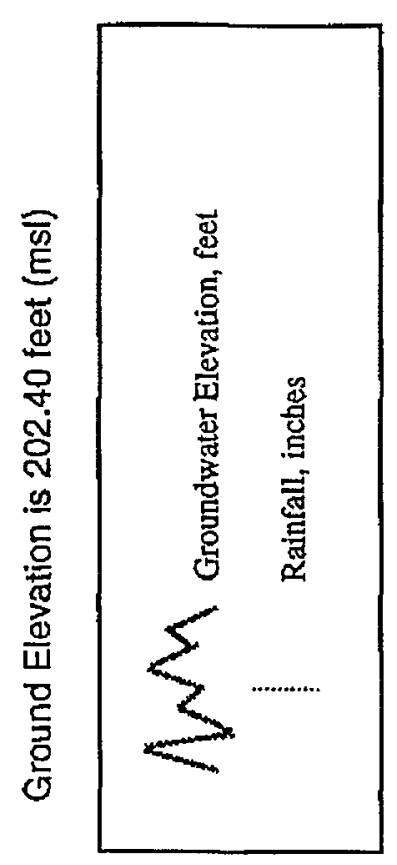

를 


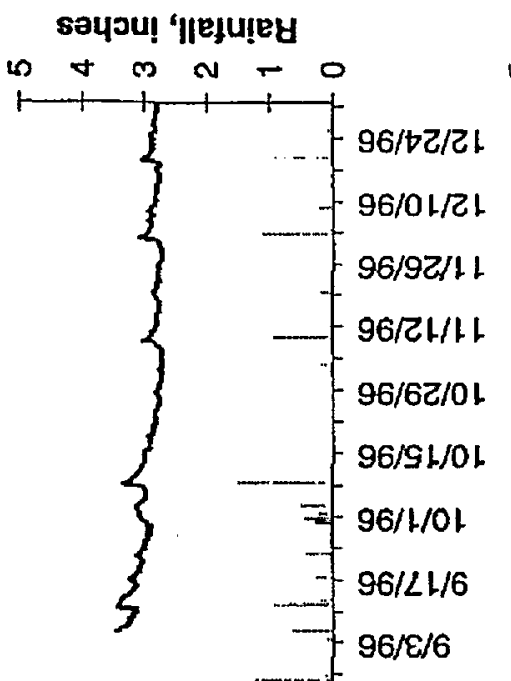

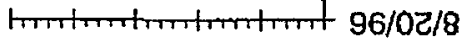

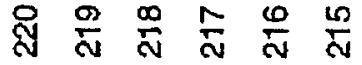

(Isu) 109! 'uo!

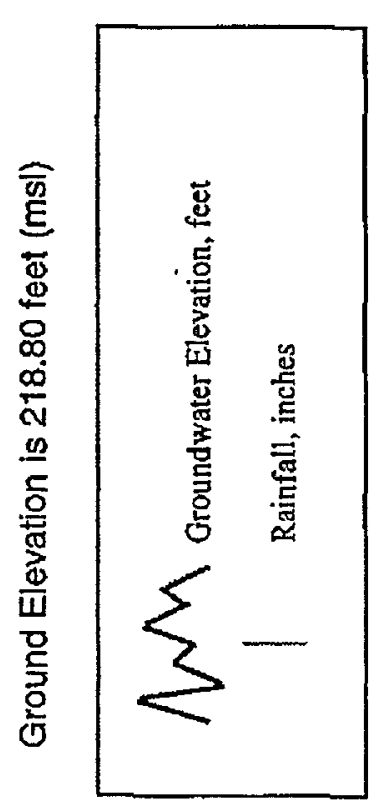

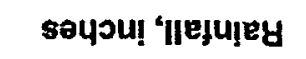

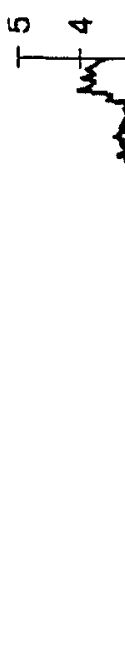



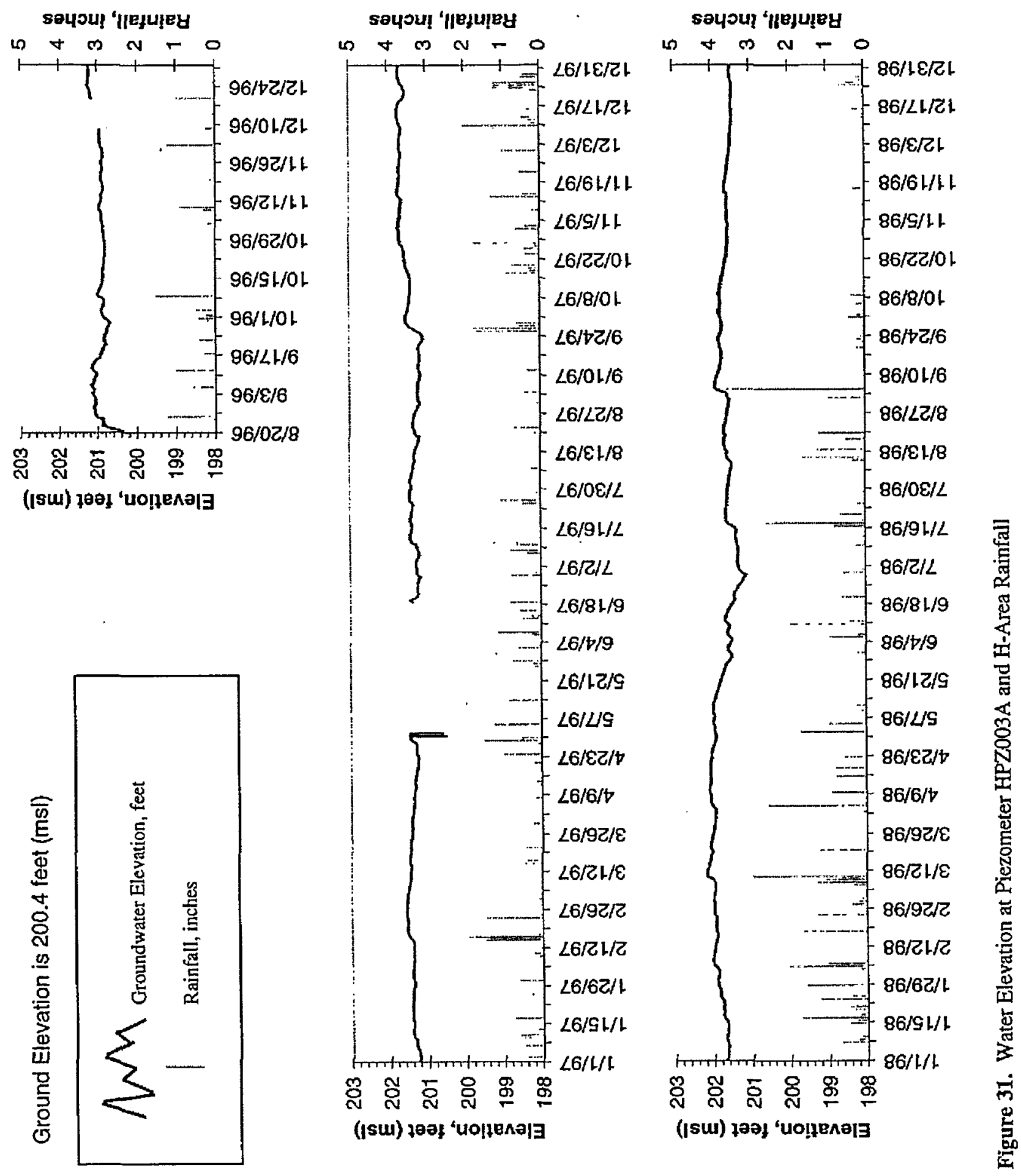

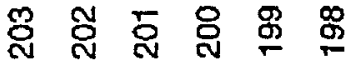

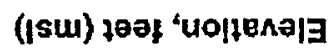



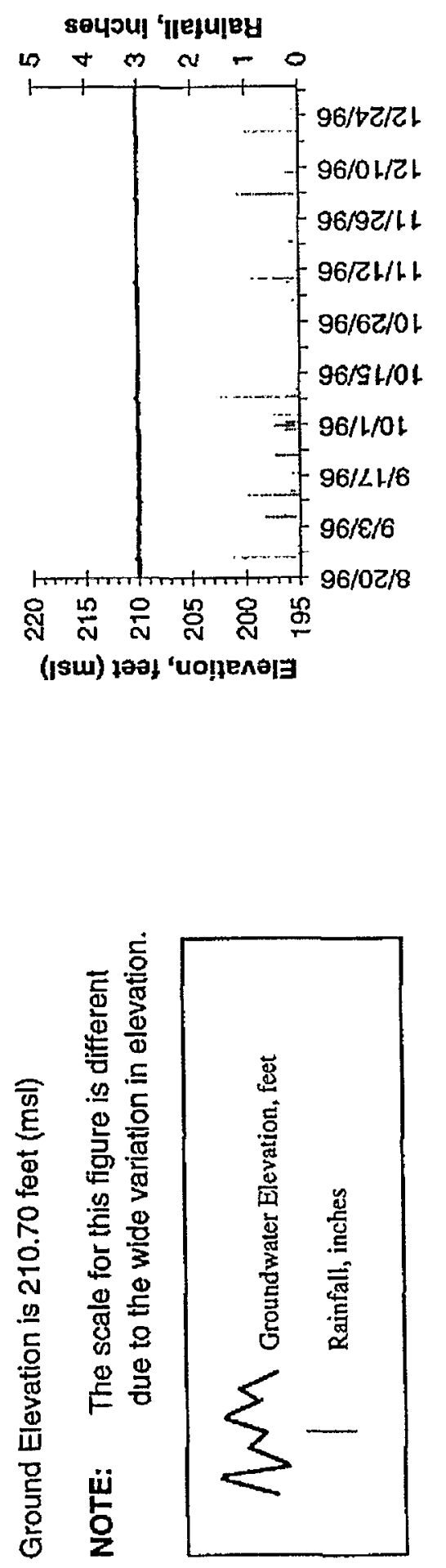

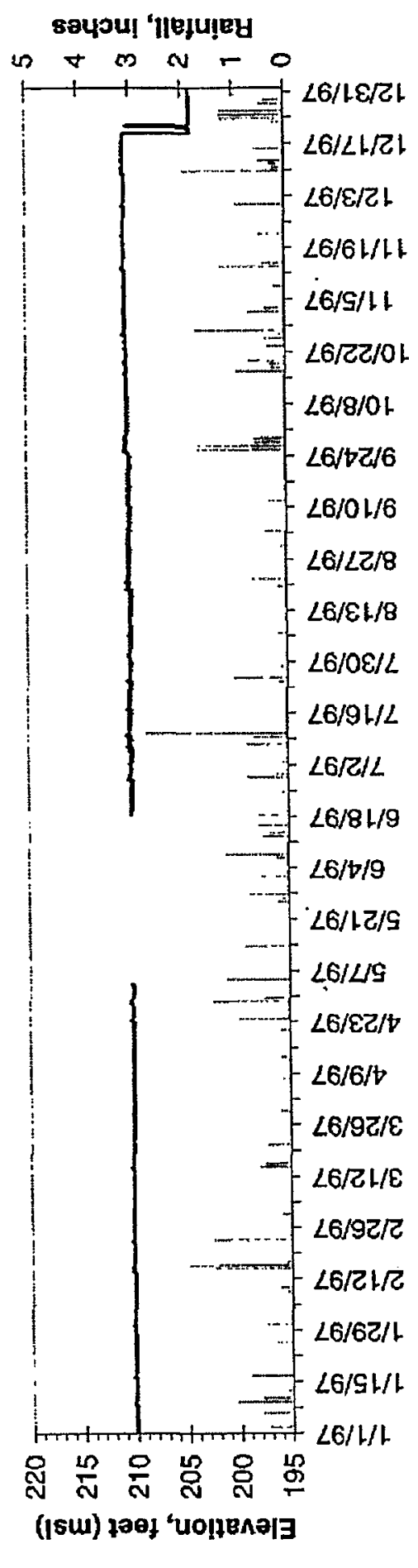

soysul 'ॉleju!ey

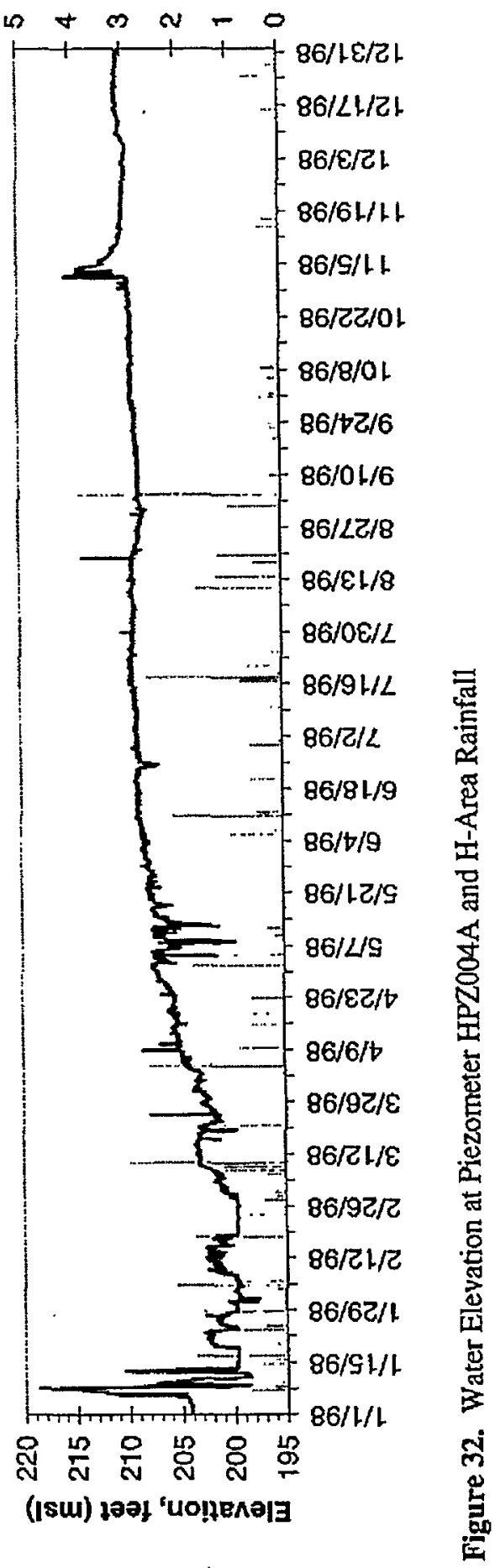




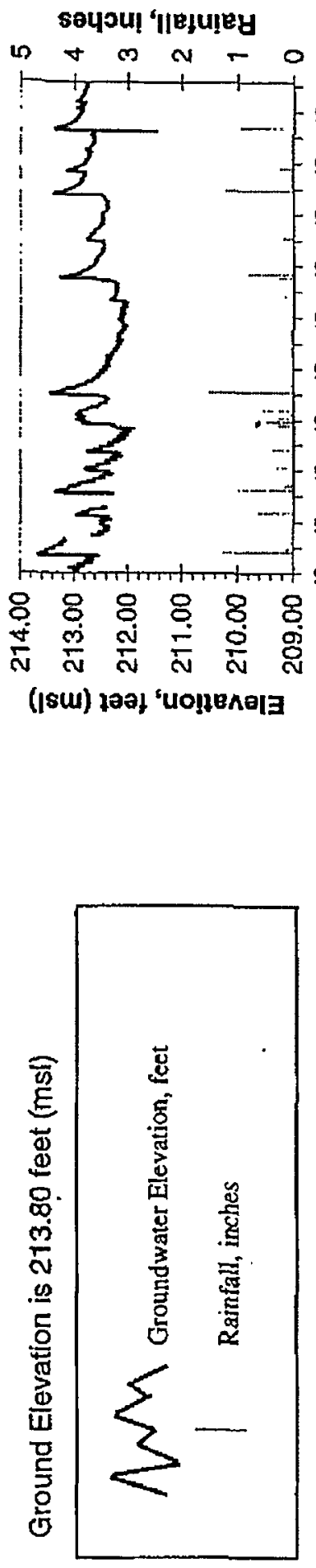

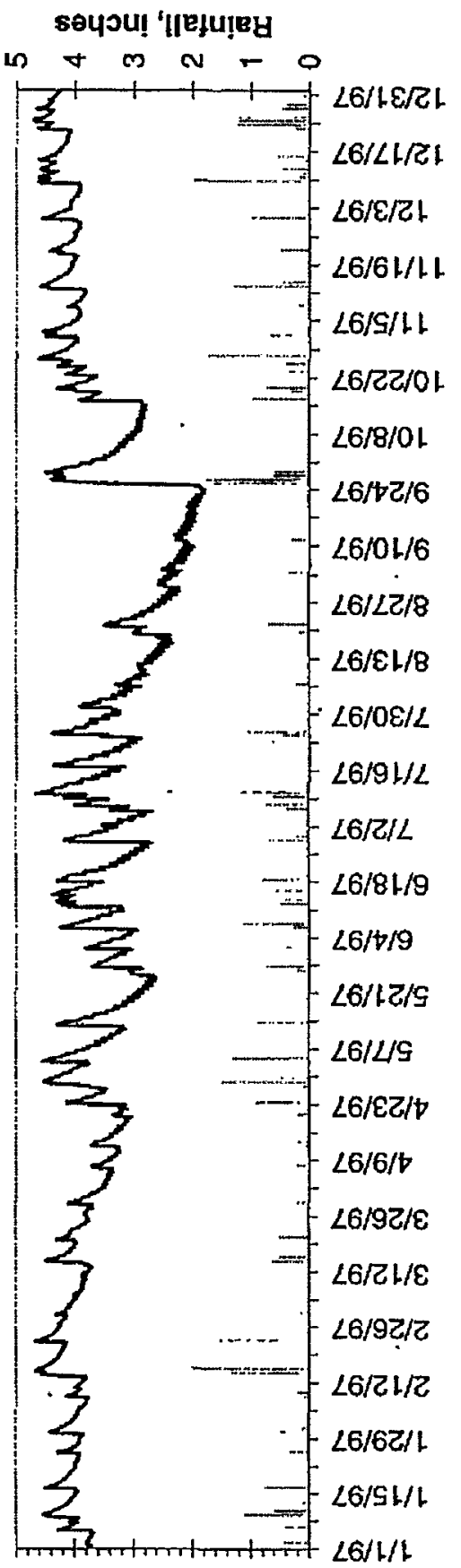

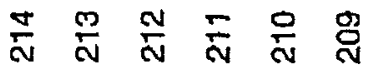

(1su) ұәə) 'uo!fen키

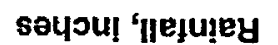

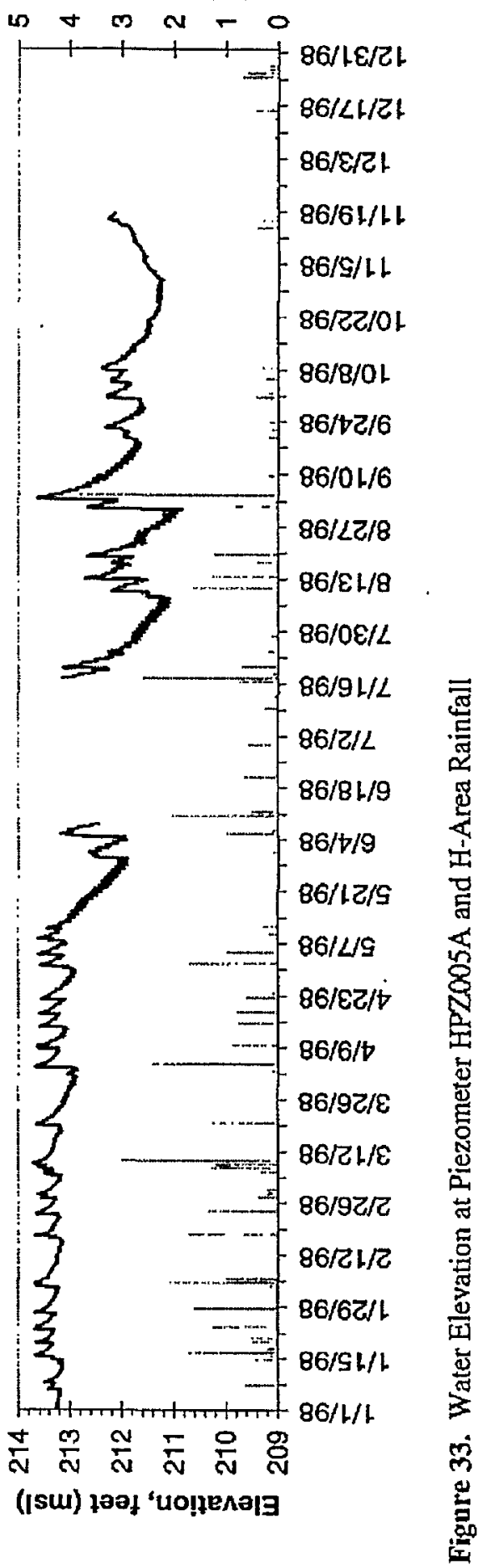




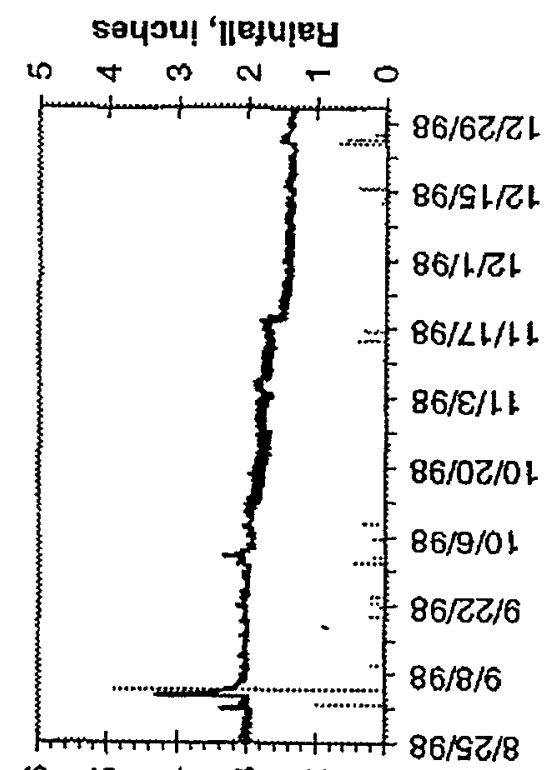

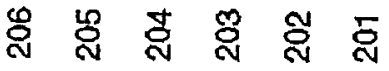

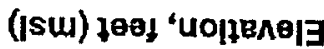

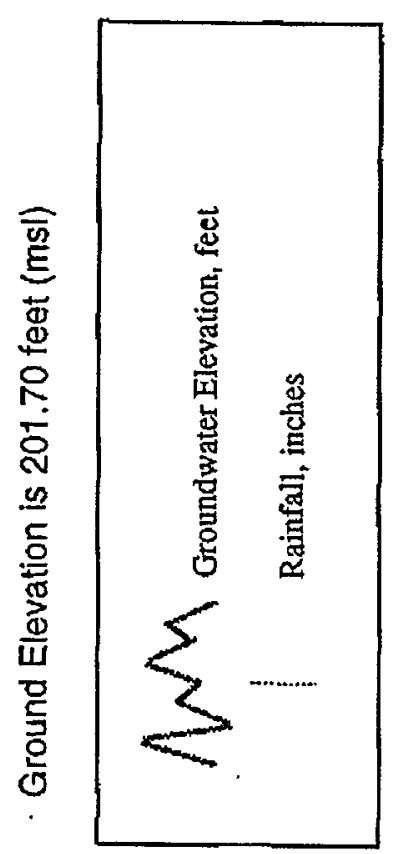

究 


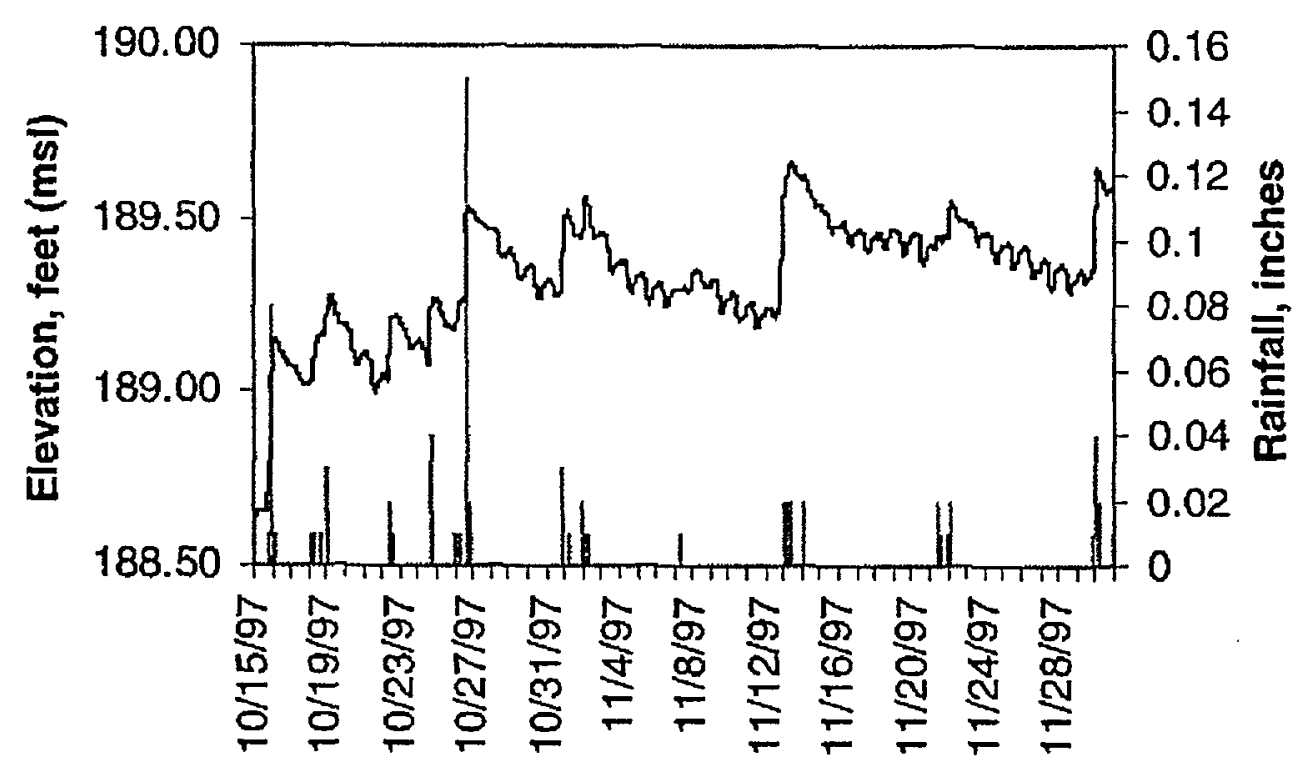

Figure 35. Typical Groundwater Response to Rainfall 


\section{Water Elevation at FPZO02A}

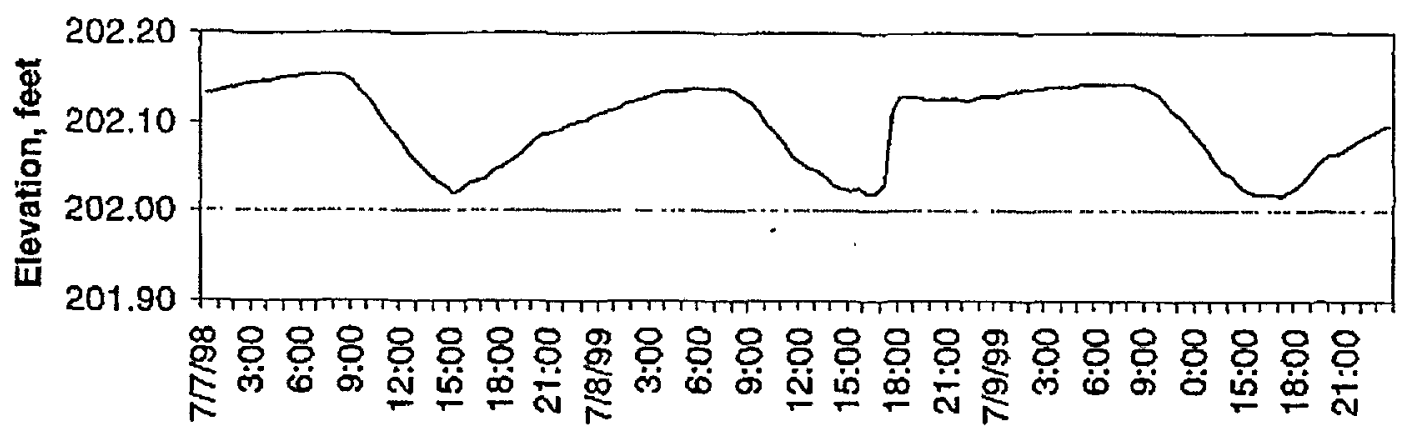

\section{Water Elevation at HPZ002A}

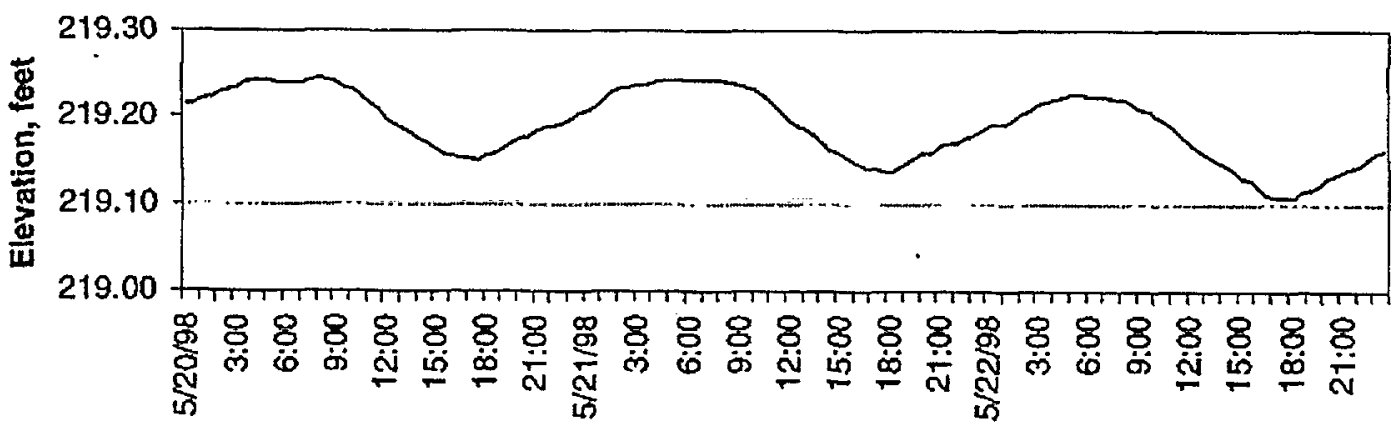

Figure 36. Typical Diurnal Pattern in Groundwater Elevation 